Article

\title{
Spatial Pattern of Agricultural Productivity Trends in Malawi
}

\author{
Leah M. Mungai ${ }^{1, *}$, Joseph P. Messina ${ }^{2}(1)$ and Sieglinde Snapp ${ }^{3(0)}$ \\ 1 Department of Geography, Environment and Spatial Sciences, and Center for Global Change and Earth \\ Observations, Michigan State University, East Lansing, MI 48823, USA \\ 2 College of Arts and Sciences, The University of Alabama, Tuscaloosa, AL 35487, USA; jpmessina@ua.edu \\ 3 Department of Plant, Soil and Microbial Sciences, and Center for Global Change and Earth Observations, \\ Michigan State University, East Lansing, MI 48823, USA; snapp@msu.edu \\ * Correspondence: mungaile@msu.edu
}

Received: 18 December 2019; Accepted: 6 February 2020; Published: 11 February 2020

\begin{abstract}
This study aims to assess spatial patterns of Malawian agricultural productivity trends to elucidate the influence of weather and edaphic properties on Moderate Resolution Imaging Spectroradiometer (MODIS)-Normalized Difference Vegetation Index (NDVI) seasonal time series data over a decade (2006-2017). Spatially-located positive trends in the time series that can't otherwise be accounted for are considered as evidence of farmer management and agricultural intensification. A second set of data provides further insights, using spatial distribution of farmer reported maize yield, inorganic and organic inputs use, and farmer reported soil quality information from the Malawi Integrated Household Survey (IHS3) and (IHS4), implemented between 2010-2011 and 2016-2017, respectively. Overall, remote-sensing identified areas of intensifying agriculture as not fully explained by biophysical drivers. Further, productivity trends for maize crop across Malawi show a decreasing trend over a decade (2006-2017). This is consistent with survey data, as national farmer reported yields showed low yields across Malawi, where 61\% (2010-11) and 69\% (2016-17) reported yields as being less than 1000 Kilograms/Hectare. Yields were markedly low in the southern region of Malawi, similar to remote sensing observations. Our generalized models provide contextual information for stakeholders on sustainability of productivity and can assist in targeting resources in needed areas. More in-depth research would improve detection of drivers of agricultural variability.
\end{abstract}

Keywords: agriculture; productivity; Normalized Difference Vegetation Index (NDVI); proxies; intensifying

\section{Introduction}

\subsection{Background on Agriculture Production}

Agriculture systems offer multi-functional services that support and regulate natural services, as well as provide income, food, fodder, and fuel [1,2]. Variation on climate and land use changes have impacted vegetation patterns and global ecosystem resilience [3,4]. In many low latitude countries, climate change, population pressures, and socio-economic inequity have posed challenges to food production [5].

Sub-Saharan Africa is a vulnerable region for agriculture production. The predominant smallholder agriculture systems are rain-fed with limited use of inputs [6]. Recent studies show that shrinking farm sizes are associated with increasing population pressures, however, farm productivity trends in these areas are also influenced by socio-economic drivers and institutional policies, resulting in a wide range of agricultural pathways, from extensification to intensification [6,7]. Past studies show that food production can be improved through sustainable intensification practices [8]. 
Sustainable Intensification (SI) of agriculture optimizes agricultural resource use to produce more food per unit, area of land, while conserving and protecting the environment $[9,10]$. There remain conflicting scientific ontologies and sustainable intensification solutions: Some researchers suggest revisiting the theories driving sustainability, while others propose consideration of 'ecological intensification' as an alternative concept in which biological processes, rather than chemical inputs, support environmentally-friendly production systems [11,12].

Research on SI strategies mainly focuses on field experimentation and community level studies, with limited research that addresses SI practices at the sub regional through national scales, and involving biogeographic conditions across different spatial and temporal scales [13].

\subsection{Crop Production in Malawi}

Malawi is among the food insecure countries in Sub Sahara Africa. However, Malawi does have unique drivers that make it an interesting study; rainfall patterns are changing, with notable extreme weather events in past decades [14,15], and has typically low nutrient soils due to inadequate resource inputs and continuous maize cultivation [16]. Socio-political factors such as colonial models of land resource management [17], access to education, and health-HIV/AIDS combine to increase food insecurity vulnerability at both household and community levels, and these drivers vary across the country [18].

The Malawian government has taken steps to increase agricultural production through the Fertilizer Input Subsidy Program (FISP) that provided farmers with input resources such as improved seeds and inorganic fertilizer [19]. Malawi's district based agricultural extension services system (DAESS) was involved in the promotion of FISP and innovative interventions aimed to assists farmers in improving farm productivity and livelihoods [20]. In recent years, there have been debates on whether and to what extent maize yields and productivity increased, as remote sensing productivity trends are flat or declining, and are not in line with Malawi maize yield statistics [21,22].

Additionally, since the early 2000s, the Government of Malawi has invested in smallholder scale irrigation development, implemented through the Malawi Ministry of Agriculture, Irrigation, and Water Development with partners from international donor communities [23]. Two irrigation projects enhancing crop production in medium and small farming communities across Malawi are the Smallholder Irrigation and Value Addition Project (SIVAP) and the Shire River Basin Management Programme Project (SRBMP) [24]. As of 2014, irrigated cropland in Malawi was 4\%, or 104,000 hectares; these comprise $46 \%$ estates, and 54\% smallholder owned, and mainly grow maize, rice, sugarcane, and vegetables [25].

Some studies show that smallholder farmers who have access to inputs and participate in agricultural system interventions often have improved farm productivity and are likely to practice mixed-maize systems, which includes crops such as millet, root crops, pulses, and fruit trees for local consumption [26]. Additionally, studies have reported that smallholder systems can increase biological and environmental resilience through application of perennial crops and legume diversification [27,28].

Few studies of smallholder agricultural development capture long-term performance or multidimensional scaling [11,22]. There remains a knowledge gap in scaling across multiple mapping extents and political boundaries using explicit measures of agriculture intensification across time and scale. Measuring and identifying spatial-temporal patterns of intensification of agriculture is critical for the development of rain-fed smallholder farming systems, as this is linked to improving farmer livelihood and food security. The main purposes of this study are to establish sustainability indicators in a regional context and identify locations and patterns of agricultural intensification in Malawi. This study seeks to improve our understanding of agricultural intensification and associated spatial and temporal patterns. Our primary question is "where is agriculture productivity intensifying in Malawi?" Our null hypothesis is "locations with increased trends in agricultural productivity are intensifying". To locate areas where intensification of agriculture occurs, we propose to use remote satellite imagery 
to develop proxies to identify productivity trends that are not influenced by good climate conditions and soils.

\subsection{Proxies}

The intensification of agriculture has a strongly spatial character. Capturing agricultural intensification patterns requires empirical analyses that embed space-time interactions [29,30]. Remotely sensed time series datasets offer the requisite archival observations, allowing agricultural modeling over both space and time [31]. The significance of remote sensing time series data derived indicators then is to supply information indirectly through measurements as proxies of smallholder farming system trends detected across spatial and temporal scales [32,33]. A proxy is a remotely sensed derived estimate of an observed phenomenon. An example of a proxy indicator is the Normalized Difference Vegetation Index (NDVI) that is used as a biomass estimate, and thus a proxy for productivity [34].

In smallholder farming systems, biophysical characteristics and farmer input resources, goals, and practices are among the main influencers of intensification. Long-term monitoring and spatial mapping of these drivers are best captured in remote sensed time series datasets [35-38]. To understand this complex system of food production, we develop our geographic theory of intensification, where we observe a pixel over time for intensifying agriculture and theorize that potential areas of intensification are found in productivity scenarios presented in Figure 1a-d. The theoretical diagrams illustrate (a) increasing, (b) stable, (c) declining productivity trends, and (d) divergent productivity trends per pixel from a single point in production. The lines present different trajectories of productivity. For example, a farm with low productivity might increase production over time, whether through increased labor, fertilizer, or sustainable practices (A-Low). Further, this might be in response to improving, stable, or worsening climate and edaphic conditions. In Figure 1d, divergent trajectories might emerge from places with identical biophysical endowments as starting condition, and disentangling those trajectories and identifying those locations elucidates the manifestation of sustainable farming.
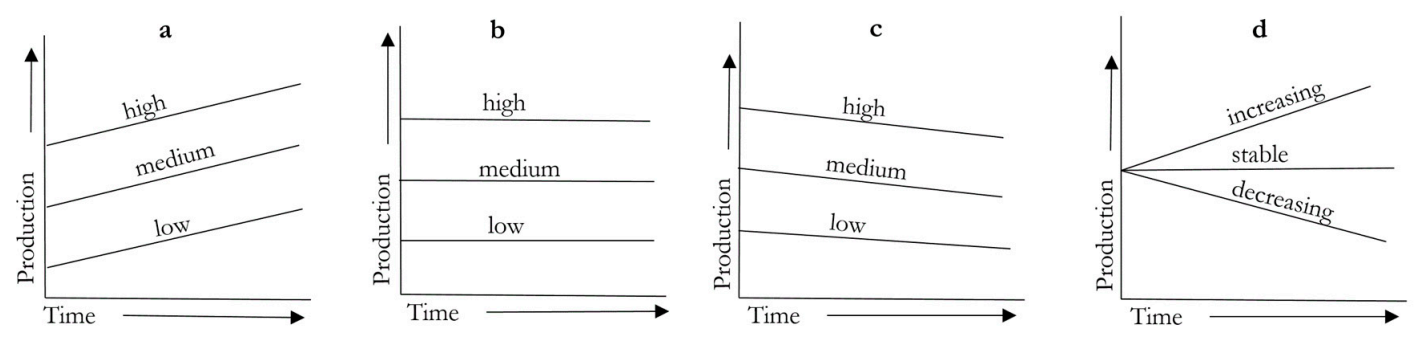

Figure 1. Theoretical model of trends in agricultural productivity per pixel over time. (a) Increasing productivity trends, (b) stable productivity trends, (c) decreasing productivity trends with a potential of pixel shifting from low getting medium or medium getting high where intensification of agriculture is occurring. (d) Divergent productivity trends from a single point in production.

\section{Malawi-Study Area}

Malawi is a small country located in southeastern Africa. The country occupies approximately $118,480 \mathrm{~km}^{2}$, one-fifth of which is covered by Lake Malawi [39], (Figure 2). Malawi has complex topography along the latitudinal gradient of the rift valley, contributing to diverse geographical gradient [40], including low Shire Valley plains $(<200 \mathrm{~m})$, Lake Malawi shore, middle and upper Shire (200 to $760 \mathrm{~m}$ ), mid-elevation upland plateau $(760$ to $1300 \mathrm{~m})$ and highlands ( $>1300 \mathrm{~m})$ plateaus [41]. 


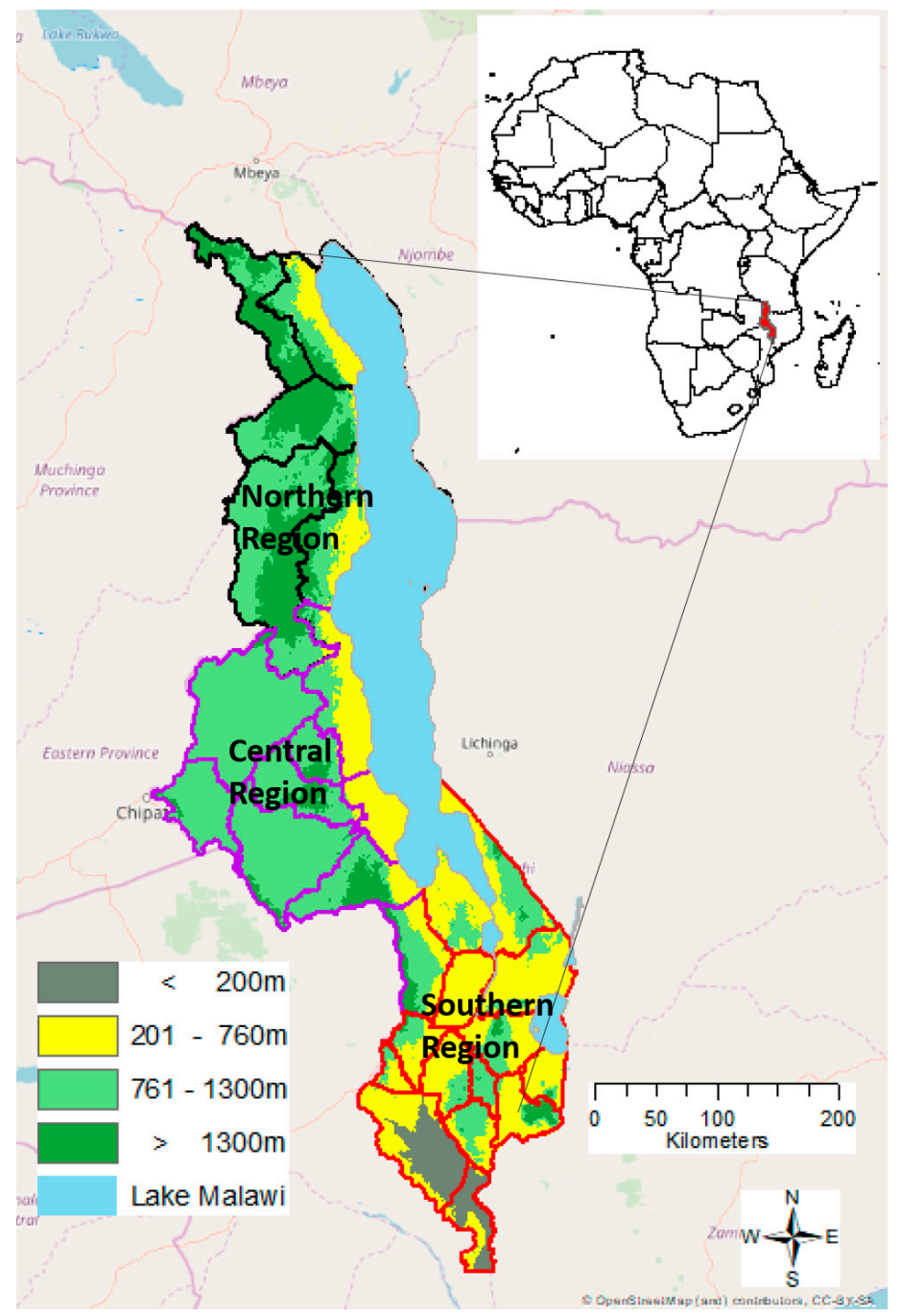

Figure 2. Study Area displaying three aspects: Agroecology zones based on elevation above sea level, district boundaries, and the three administrative regions of Malawi; Northern, Central, and Southern regions (District boundaries shown).

Malawi's uni-modal climate is influenced by the latitudinal (north-south) shifting of the intertropical convergence zone (ITCZ) [39]. The rainy season starts in mid-October, peaks in January, and extends through to early March or April, while the dry season starts from May to early October (Malawi Meteorology Services). In Malawi, climate change manifests as seasonal shifts in rainfall pattern, such as the number of dry days and extreme events [15,42]. Average temperatures range from $29^{\circ} \mathrm{C}$ in October to $7{ }^{\circ} \mathrm{C}$ in February, and average annual rainfall is between $725 \mathrm{~mm}$ and $2500 \mathrm{~mm}$ (Malawi meteorology services). Malawi has a rapidly growing population, from 15 million people in 2012 to a projected 26 million by 2030 [43], with a majority (85 percent) of Malawians living in rural areas and making their livelihood from agricultural production $[44,45]$.

\section{Data}

The datasets used in this study include: Long term vegetation estimated from Moderate Resolution Imaging Spectroradiometer (MODIS), 16 days interval-Normalized Difference Vegetation Index (NDVI)-MOD13Q1 version 6, at 250 m (https://doi.org/10.5067/MODIS/MOD13Q1.006) [46]. Precipitation dataset is derived from MODIS-Climate Hazards group Infrared Precipitation with Stations (CHIRPS) data product at $1 \mathrm{~km}$ resolution for precipitation [47], and MODIS-8 day Interval-Land Surface Temperature (LST) MODIS11A2.006, representing surface temperature at $1 \mathrm{~km}$ spatial resolution 
(https://doi.org/10.5067/modis/mod11a2.006) [48]. Ancillary datasets to derive long term agriculture include: MODIS Land Cover at $500 \mathrm{~m}$ (https://doi.org/10.5067/MODIS/MCD12Q1.006) [49]. Glob Cover 2009 land cover at $300 \mathrm{~m}$ resolution http://due.esrin.esa.int/page_globcover.php) [50], FAO-Africover 2010 at 30 m resolution, European Space Agency (ESA) time series 1992 to 2015 land cover at $300 \mathrm{~m}$ resolution [51], and a Malawi's soil suitability spatial distribution product from [52] were used for our analysis (Table 1).

Table 1. Climatic and land cover datasets used to determine productivity trends and intensification of agriculture.

\begin{tabular}{llll}
\hline Dataset & Time Span & Resolution & Source \\
\hline $\begin{array}{l}\text { Land Surface Temperature (LST) } \\
\begin{array}{l}\text { MODIS/006/MOD11A2-8-day } \\
\text { interval }\end{array}\end{array}$ & $2006-2017$ & $1 \mathrm{~km}$ & NASA EOSDIS \\
$\begin{array}{l}\text { NDVI MODIS/006/MOD13Q1 } \\
\begin{array}{l}\text { UCSB-CHG/CHIRPS/DAILY } \\
\text { rainfall data }\end{array}\end{array}$ & $2006-2017$ & $250 \mathrm{~m}$ & NASA EOSDIS \\
$\begin{array}{l}\text { Malawi land suitability } \\
\text { Annual global land cover time series }\end{array}$ & $1996-2017$ & $5 \mathrm{~km}$ & UCSB/CHG \\
$\begin{array}{l}\text { MODIS MCD12Q1 Land cover } \\
\text { Global land cover GlobCover }\end{array}$ & $2006-2017$ & $500 \mathrm{~m}$ & $\begin{array}{l}\text { European Space Agency (ESA) website } \\
\text { (https://www.esa-landcover-cci.org/) }\end{array}$ \\
$\begin{array}{l}\text { FAO-Africa Cover Malawi's Land } \\
\text { Cover Product }\end{array}$ & $2009-2010$ & $300 \mathrm{~m}$ & $\begin{array}{l}\text { European Space Agency (ESA) website } \\
\text { (https://www.esa-landcover-cci.org/) }\end{array}$ \\
\hline
\end{tabular}

\section{Methods}

\subsection{Measurement of the Spatial Distribution of Productivity}

We use biomass estimates as a proxy for productivity by taking the 10-year record of mean MOD12Q1, NDVI, 16-day interval, at $250 \mathrm{~m}$ spatial resolution during the November to April growing period for maize. This measures the onset of greenness, peak time, and maximum NDVI in one growing season [53]. The mean value per pixel was computed across the growing season for each year ( $t$ ) (2007 to 2017) across Malawi [53]. To derive the trend and calculate the slope coefficients for each pixel, we used a linear function $(y=m+b t)$, where $y$ is dependent variable (NDVI), and $(t)$ time as the independent variable, and apply the model over the complete time series [54-56]. This linear trend technique allows per pixel comparison between NDVI and other datasets to examine long term trends, unlike using nonlinear approach, since nonlinearity would not allow clear pixel comparisons between datasets [55]. One caveat here is that our linear function does not take into account model assumptions of serial correlation [57]. However, the Mann-Kendall test was used to compute serial correlation on mean annual NDVI time series, and a Theil-Sen (TS) slope estimator was computed on mean annual NDVI to identify significant trends $[58,59]$. This method handles seasonality more efficiently than the trend-over time linear model [60,61]. Additionally, Mann Kendall's decomposition function separates deterministic series from the original data time series and breaks down the data seasonality from the trend, and remaining or random data as the annual anomalies [60]. The observed NDVI trends from the maize growing season over time are classified into high, minimal change, and low trends using equal interval classification in ArcGIS to determine NDVI signal attributed to high, minimal change, and low pixel values. We use minimal change term for precision in our analysis, pixels with minimal change are referred to as stable; these two terms are used interchangeably in the study. Stable production can be an indicator of sustainability as climate or other conditions decline. 


\subsection{Biophysical Drivers}

We calculate average values on the MODIS 11A2 -8-day interval temperature and precipitation time series from the growing season (November to April) over 2006 to 2017, to derive the trend and slope coefficients for each pixel, as previously described with the NDVI dataset above. A linear function is developed on both the temperature and precipitation datasets $(y=m+b t)$, where $y=$ the dependent variable as the (LST_Day_1 $\mathrm{km}$ band) for temperature, and precipitation estimates for precipitation, while $(t)=$ time per year over a ten-year period, independent variable.

\subsection{Malawi Land Cover}

Malawi's agricultural lands were identified using four different land cover products: FAO-Africover 2010 product at $30 \mathrm{~m}$ resolution, European Space Agency (ESA) 1992 to 2015-time series land cover at $300 \mathrm{~m}$ resolution, Glob-Cover 2009 land cover at $300 \mathrm{~m}$ to look at intensification aggregates, and the MODIS Land cover from 2000 to 2013 at $500 \mathrm{~m}$ that uses land cover assessment from five global land cover classification systems.

We resample all low spatial resolution land cover data sets to the finest spatial resolution of $30 \mathrm{~m}$ using nearest neighborhood sampling method, and use a binary reclassification for the agricultural classes, and nonagricultural classes. The four land cover layers are summed, resulting in a combined output with five agricultural class categories $0,1,2,3$, and 4 . The ' 0 ' category are pixels classified as non-agriculture based on the combined land cover class product, while " 1 " is some agriculture, and '2, 3, 4' pixel categories have increasingly reported agricultural cover, and are representative of Malawi's agricultural land area of 50,236 km², which differs only slightly from the FAO 2010 cropland area of $55,720 \mathrm{~km}^{2}[62]$.

\subsection{Land Suitability Spatial Distribution}

Most of the agricultural land in Malawi is degraded or of marginal quality due to continuous cultivation and expansion onto hill slopes [52]. To characterize agricultural suitability, we used the spatial distribution of land suitability product developed by [52], which addresses land favorable for cultivation based on topographical conditions, that is; terrain, soil erosion risk, and soil characteristics such as texture, soil organic carbon (SOC), $\mathrm{pH}$, depth, drainage, erosion potential, Cation Exchange Capacity (CEC). We rate the land's ability for agricultural production by reclassifying the soils into: Suitable soils for crop cultivation (that represent highly suitable, moderately suitable classifications in [52]) and poor soils (marginally suitable, and unsuitable soils in [59]).

\subsection{Spatial Distribution of Productivity, Soil Suitability, Precipitation, and Temperature}

The spatial distribution of agricultural production incorporating climate and edaphic conditions is derived via a two-step process. In the first step, multiple datasets; NDVI (productivity), soil suitability, and climate pixel values calculated from above section are imported into ArcGIS. Each dataset; NDVI, soil suitability, and climate values are reclassified into categories, that is; NDVI increasing, minimal change, decreasing trends $(1,2,3)$, temperature increasing/decreasing trends $(1,0)$, precipitation increasing/decreasing trends $(1,0)$ and soil suitable and unsuitable classes $(1,0)$. These multiple datasets are combined to derive their spatial information using spatial analysis combine feature in ArcGIS environment, where a total of 40 unique combinations are realized. The 40 unique realization layer is superimposed to agricultural layer, and all non-agricultural areas are masked out. Figure 5 shows the 40 combinations of the four variables (productivity $(\mathrm{P})$, rainfall $(\mathrm{R})$, soil $(\mathrm{S})$, and temperature $(\mathrm{T})$ ) we analyzed. In the second step, we identify locations of potentially intensifying agriculture, we query for pixels where increasing productivity is not driven by good climate and suitable soils from the 40 unique realization layer from step one above.

We use high spatial resolution satellite imagery from Google Earth Pro to carry out a visual inspection of identified intensifying agriculture pixels above. The intensifying pixels' layer was 
rendered in Google Earth Pro, we used archived Landsat satellite images of 30-m resolution found between 2013 to 2016 for Malawi growing season and dry season captured to determine the land use in the "intensification" pixels. We randomly zoomed into locations in the north, central, and southern Malawi, where these increasing productivity pixels seem to be located, that is mostly in mountainous, forested, or flood plain areas.

\subsection{Agricultural Input Resource Management}

To explore social drivers of agricultural production, and disentangle these social drivers from intensification, we present farmer reported yields and input practices as reported by farmers interviewed in two cross sectional instrument surveys: Third Integrated Household Survey-2010-2011 and Fourth Integrated Household Survey-2016-2017 Living Standards Measurement Study (LSMS), respectively, implemented by the Malawi National Statistical Office [63-65] These surveys were used to monitor and evaluate the Malawian households for poverty and vulnerability, to assist with evidence-based policy formulation for strategic national development [66]. The Integrated Household Surveys-IHS3 was implemented between March 2010-2011 using 12,271 households and Integrated Household Survey-IHS4 was implemented between April 2016-April 2017 using 12,447 households.

We developed a database to be able to manage these data subsets and also linked each data subset using a unique identifier. We created queries to minimize data errors from the surveys, where we considered only the data where (a) farmers reported plot yields greater than 0 and less than $10,000 \mathrm{~kg} /$ hectare and also reported use of fertilizer inputs greater than 1000 grams. The 2010-2011 survey sample size was filtered to 9939 samples, similarly, 2016-2017 survey sample size was filtered to 10,757 households. Additionally, in both datasets, only maize crop information was included. The farmer reported plot yields units for both surveys were standardized to yields in Kilograms units using 2009 world bank crop conversion standards. In both surveys, we considered the agricultural management questions that asked farmers the use of organic fertilizer (Yes/No) and use of inorganic fertilizer (Yes/No) per plot. Additionally, in both surveys, farmers were asked to rate how they perceived the soil quality on their plots, as good, fair, or poor. Household geographic coordinates used in both surveys are offset approximately five kilometers from the actual physical household location for privacy reasons, and their plot geographic coordinates were recorded as distances from the household to plot location, not actual plot locations. The outputs from the database on both survey datasets above were used to create distribution maps (layers) in ArcMap software. Distribution maps created were for farmer reported yields, organic and inorganic inputs use, and soil quality responses, respectively. We overlay each layer over the identified potentially intensifying agriculture layer from Section 4.5 above.

Our models are interpreted using regions as depicted in study area Figure 1, and for ease of reference, we also distinguish locations based on their topographical features.

\section{Results}

\subsection{Descriptive Statisics of Trend Analysis}

The dominant trend apparent in Malawian agriculture is one of decline. Figure 3a, shows the mean NDVI correlation coefficient of -0.31 , significant at 0.05 level. NDVI trend declined at a value of -0.003 per year over growing season period between 2006-2017. Further examination of trend using the Mann Kendall test shows a tau value of -0.0633 , and an overall trend is negative, and the trend is worsening at a magnitude of -0.0002 for annual NDVI, significant at 0.05 level. The mean seasonal rainfall also shows a declining trend by $-13.8 \mathrm{~mm}$ per year over the 10 year growing season period, with a correlation coefficient of -0.331 , significant at 0.05 level (Figure $3 b$ ). Mean temperature displays an increasing trend of 0.1 Celsius per year over 10-year period, with a correlation coefficient of 0.26 at 0.05 significant level (Figure 3c). 


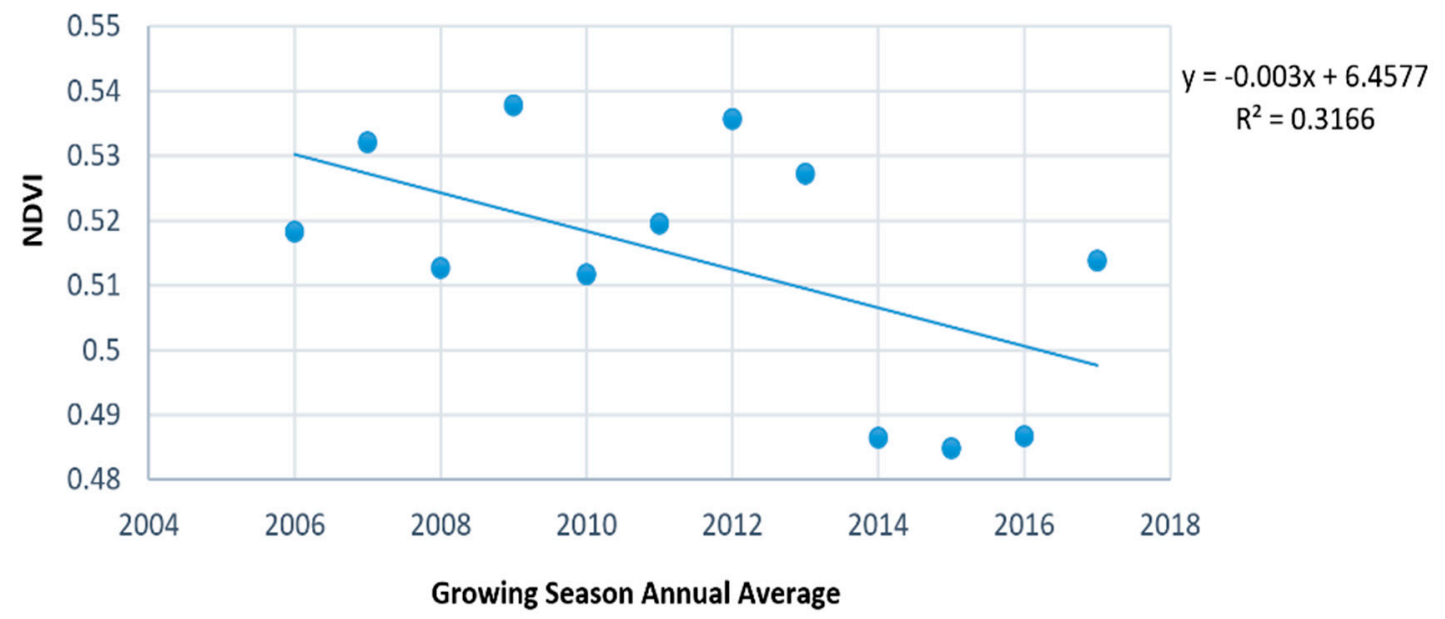

(a)

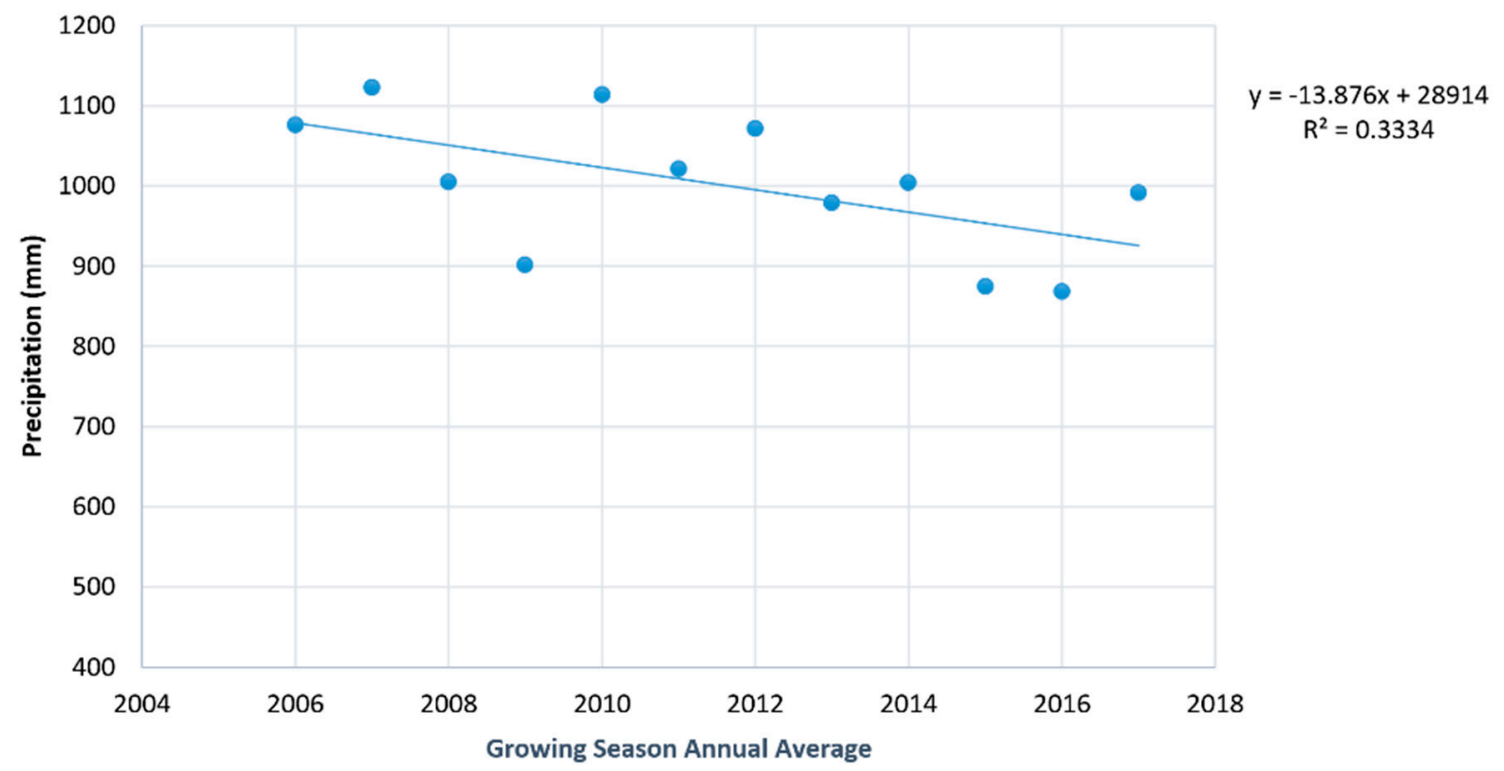

(b)

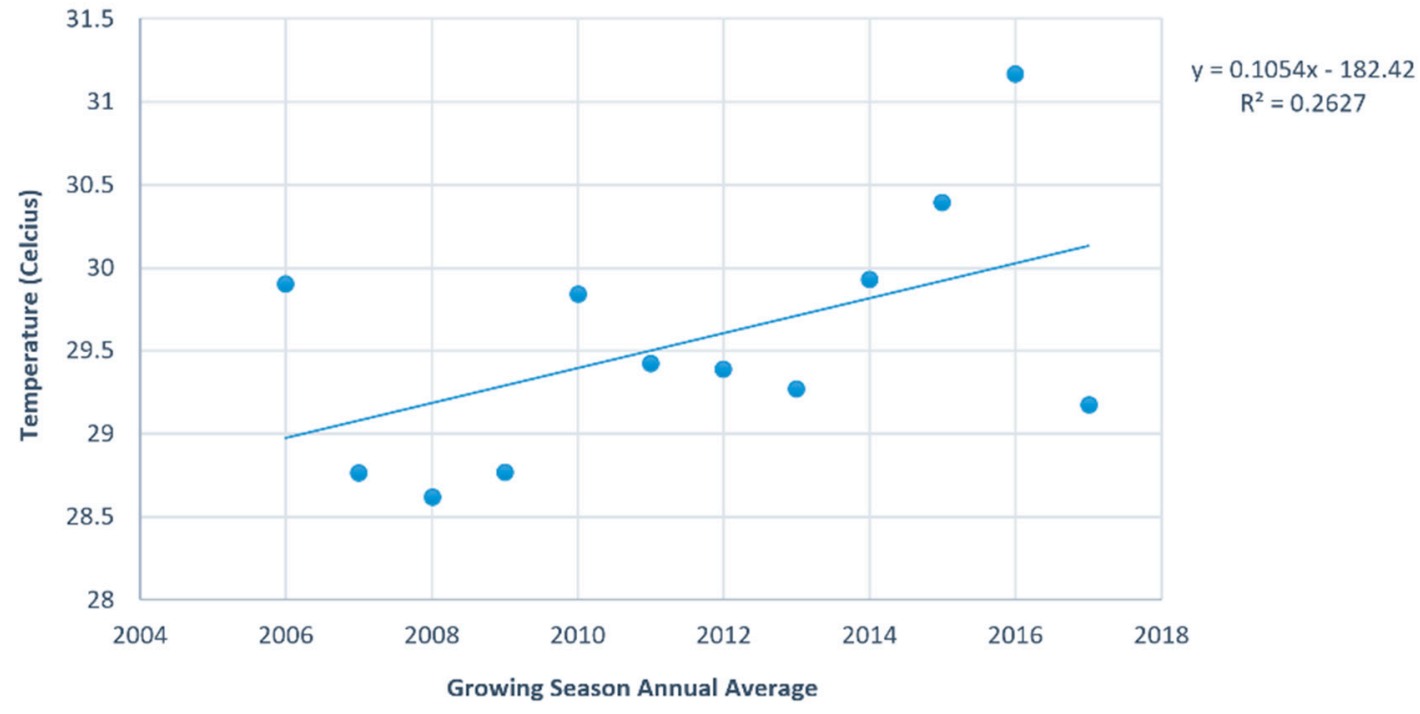

(c)

Figure 3. Annual mean trend over time including regression coefficient of (a) MODIS-NDVI, (b) CHIRPS-Precipitation, and (c) MODIS-Land Surface Temperature (2006 to 2017 time series for Malawi's main growing season (November-April). 
Decomposition of NDVI time series is shown in Figure 4. The top section is the original data series, the next is a seasonal component that illustrates the expected vegetation growing pattern from start to end of growing season, the third section is a trend component that captures distinct increases or decreases in NDVI value; declines are visible in 2009, 2012, and 2015 that coincides with observed flooding and drought events [67]. The remainder or noise component, which is the difference of the original data minus the seasonal component and direction of change-trend is shown in the last section of Figure 4.

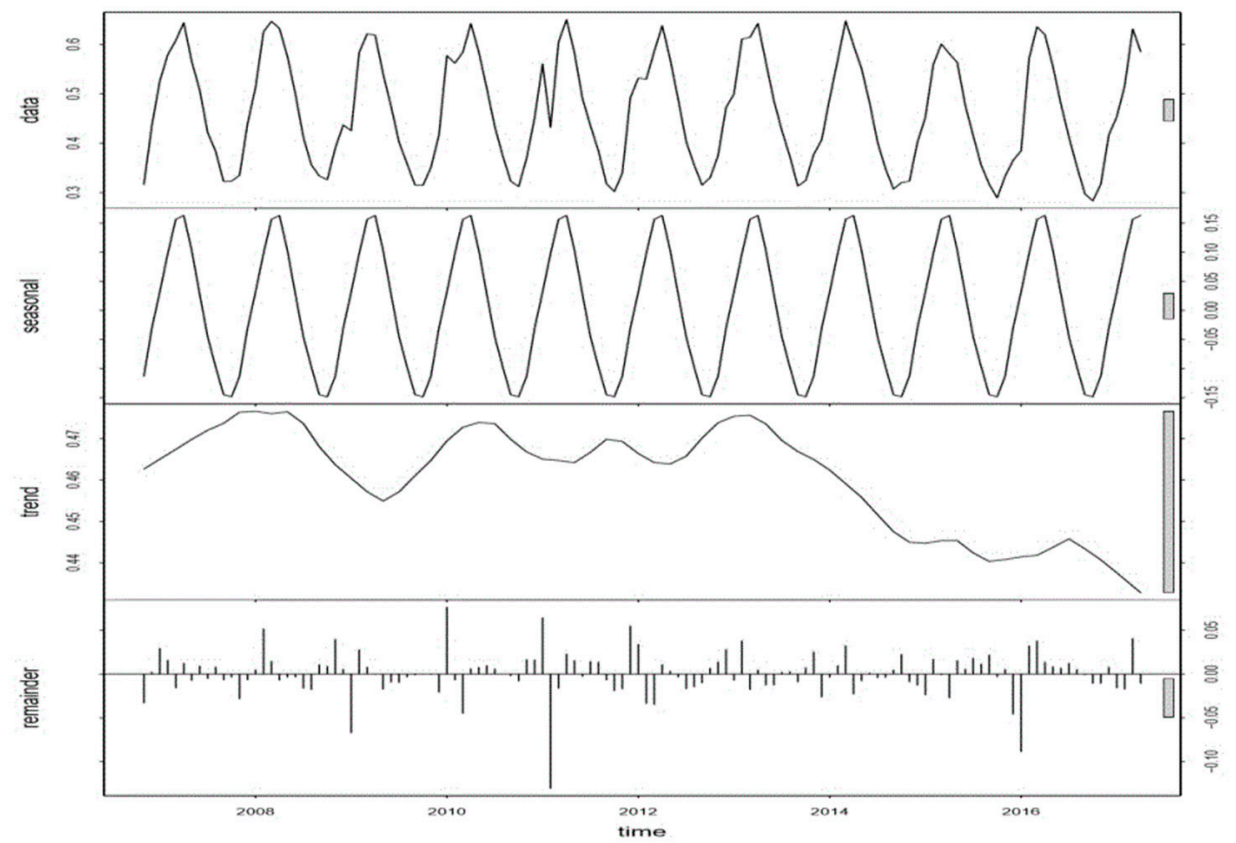

Figure 4. Mean NDVI growing season time series decomposition for Malawi. First part of graph is the original data series, second part is the seasonality component of the data, trend part of the data and remainder-that is the original data minus the seasonal and direction of change (trend). The plot has solid bars on the right hand side that show the data range and assist with comparisons.

\subsection{Spatial Distribution Pattern Analysis}

The spatial distribution map highlights the growing season NDVI slope coefficients per pixel that range from 2.5 (increase), -1.7(decrease) over 2006 to 2017 (Figure 5a). NDVI pixels in green color have increasing high slope coefficient values, these are found in the high to mid-altitude plateau areas, circled in the figure, while pixels in orange located mostly in lakeshore plains and upper Shire valley show decreasing low -1.7 value slope coefficients. Precipitation displays a latitudinal trend with increasing rainfall moving from south to north (Figure 5b). Land surface temperature exhibits decreasing trends in the northern regions and mountainous areas like Dedza in the central region and Mount Mulanje found in the south, while increasing temperature trends are found towards central and southern plains, respectively (Figure 5c).

Malawi's dominant soil texture is well-drained loamy clay sands that have adequate to low nutrient levels [68]. Overall, sandy clay loam is found across $78 \%$ of the country, with the remaining soils; $10 \%$ sandy loam, $8.4 \%$ sandy clay, and $4 \%$ blend of clay loam soils [52]. Figure $5 \mathrm{~d}$ displays Malawi's soil suitability map, illustrating that unsuitable soils are coincident with high slope areas, for example, in the Nyika highlands located in the northern region, the rift valley escarpment in the central region, and the Shire highlands in the southern region. Suitable soils are found in mid-altitude plateaus and lake plains, such as Nkhata bay. 

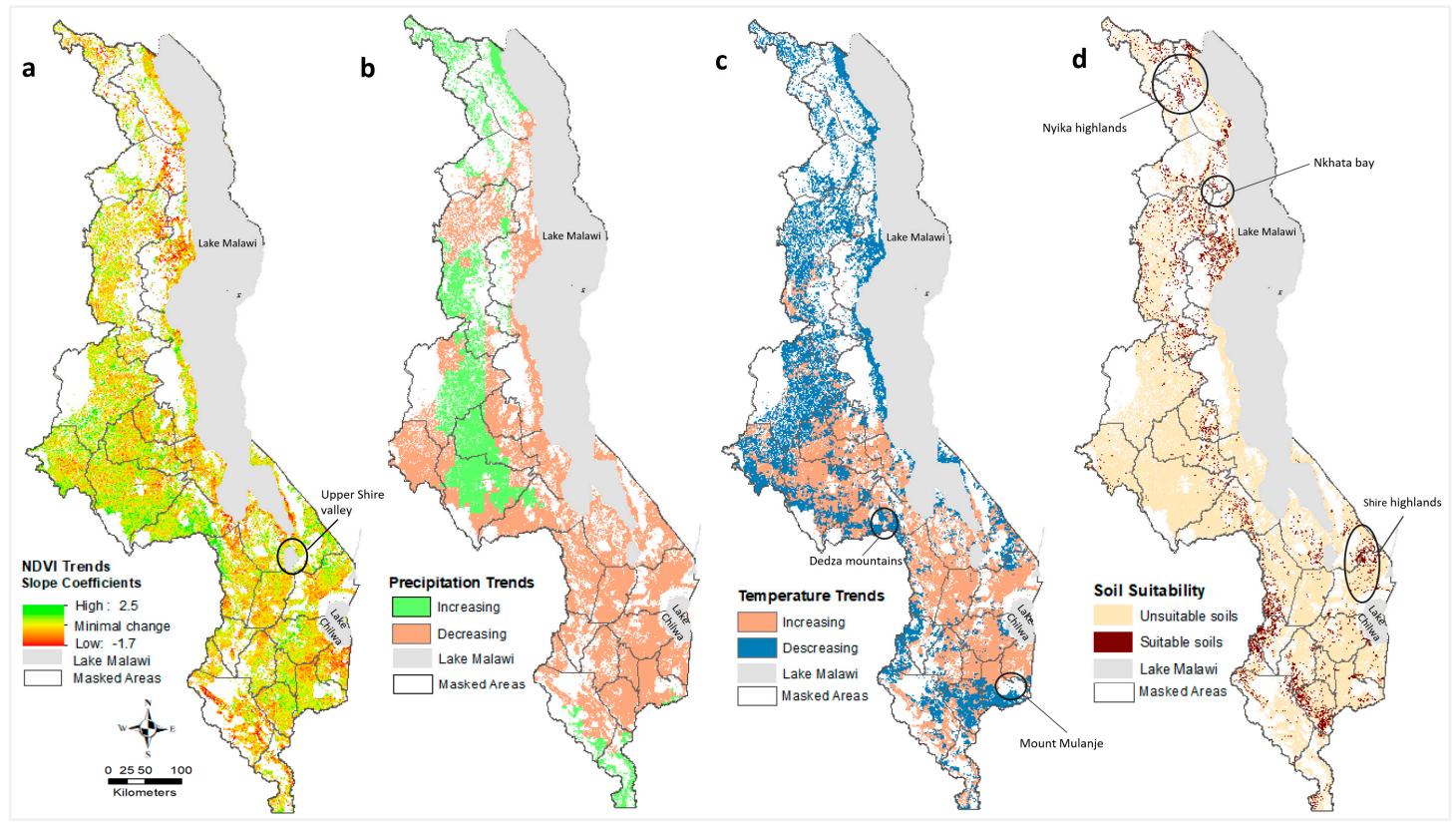

Figure 5. (a) Malawi's NDVI slope coefficients, few high pixels are seen scattered, while the majority of pixels dominate the landscape. (b) Precipitation trend displaying the latitudinal (north-south gradient); with increasing pixels shown in green color, while decreasing pixels are in orange color. (c) Land surface temperature trend displaying a latitudinal (north-south) increasing pixels (orange) and decreasing (blue). (d) Spatial distribution of soil suitability data source from [52]. In all the figures above, agriculture land cover is shown, while all other land cover types are masked out in white color.

Figure 6 shows the spatial distribution map of pixel-by-pixel combinations of NDVI, rainfall, temperature, and soil suitability, and their percentage pixels in each category. Here, the northern region has more high productivity pixels as indicated by NDVI, while others are scattered across Malawi, in high plateau areas of Dedza mountains, and the southernmost tip of Malawi (lower Shire valley). Overall, $21 \%$ of agricultural lands are associated with an increasing agricultural productivity trend. This could be largely attributed to higher levels of precipitation $(900 \mathrm{~mm}$ to $1200 \mathrm{~mm})$ in these high elevation areas, in contrast to the lower precipitation (725 $\mathrm{mm}$ to $800 \mathrm{~mm}$ ) and higher evapotranspiration in the lowlands. About $35 \%$ of agricultural lands are associated with no changes in productivity. These areas are found primarily in the central and southern regions. About $43 \%$ of all agricultural lands present decreasing productivity trends. These lands are predominantly in the southern region. Less than one percent of pixel combinations show increasing productivity trends associated with suitable soil pixels, with either decreasing rainfall and temperature trends, or vice versa.

Figure 7a,b display scenarios queried from above pixel by pixel combinations; (a) decreasing productivity trends, poor climate, and poor soils (b) stable productivity, poor climate, poor soils (c) increasing productivity, poor climate, poor soils. The pixels selected are not a composition of increasing precipitation and suitable soils, which takes $62 \%$ of all the pixels, but the remaining $38 \%$-pixel combination as potential locations where agriculture is intensifying. From these remaining pixels; $7 \%$ are located in sites that were associated with trends of decreasing productivity, lower rainfall trends, and poor soils. These sites are primarily located along Lake Malawi shore. Another $23 \%$ of sites were associated with trends of decreasing productivity, poor soils, and increasing rainfall, and were located in the central and south-west tip region of Malawi (Figure 7a). Another 7\% of sites were associated with stable productivity trends, decreasing rainfall, and poor soils are found scattered in central and along Lake Malawi shoreline (Figure 7b). These sites may represent sites of intensification. Drivers may include various social or biophysical factors, including a shorter cultivation history and forest border effect. Decreasing trends can be associated with temperature-induced drought stress in these regions based on the different years of irregular rainfall or heavy downpours that flooded areas close 
to water bodies, based on the Government of Malawi floods and drought alerts in April 2016, and flooding incidents in 2017 [69,70]. Figure 7c displays increasing high productivity trends in areas with decreasing rainfall, and unsuitable soils, $0.07 \%$ of these pixels are found in the south-east lower areas in the floodplains of Shire river and Lake Chilwa, while in the central regions, the pixels are adjacent to forest cover masked areas.

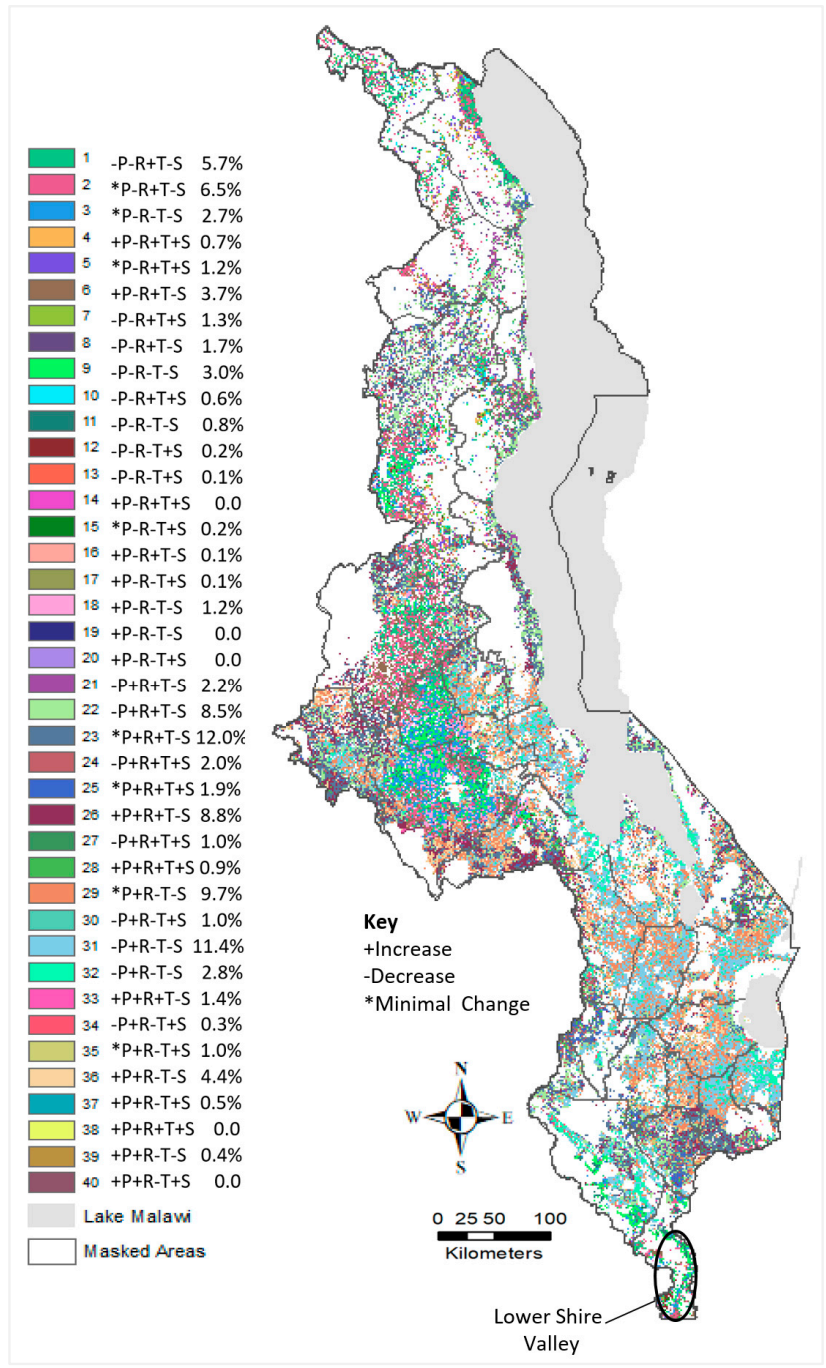

Figure 6. Spatial distribution of all pixel by pixel possible combinations of the four maps from Figure 5 of variables under study NDVI (P), Soil (S), Temperature (T), and Rainfall (R). Agriculture land cover is displayed; all other land cover types are masked out.

Figure 8a,b displays the Malawi farmer reported yields in Kilogram per Hectare (Kg/Ha) during 2010-2011 and 2016-2017 from the national LSMS-IHS3/4 surveys overlaid on the intensifying areas layer. In 2010-2011 surveys, $61 \%$ of farmers reported yields below $1000 \mathrm{Kg} / \mathrm{Ha}$. Of these households, $37 \%$ are located in the southern region, while the central region has $14 \%$, and the northern region has $10 \%$. Households with yields between $1000-2000 \mathrm{Kg} / \mathrm{Ha}$ make up $25 \%$ of farmers, and are found in few areas in the north at $10 \%$, and in central region at $14 \%$, while $13 \%$ of farmers were found in the south region. Households with yields between $2000-3000 \mathrm{~kg} /$ Ha make up $8 \%$ scattered across Malawi. Households with yields greater than $3000 \mathrm{Kg} / \mathrm{Ha}$ are sparsely distributed across Malawi, and make up less than $6 \%$ of households. These high productivity farms are mostly located in the southern and central regions. 
a

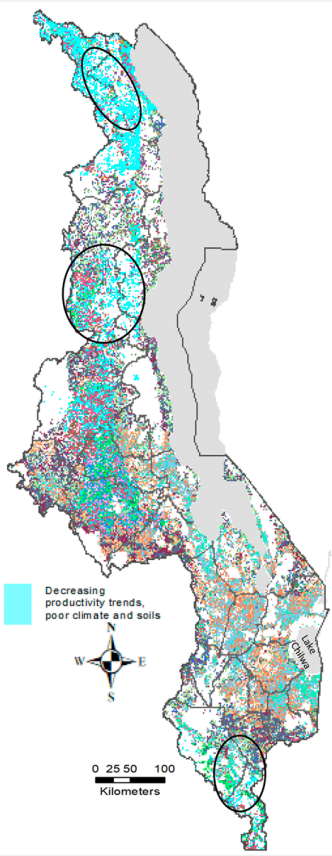

b

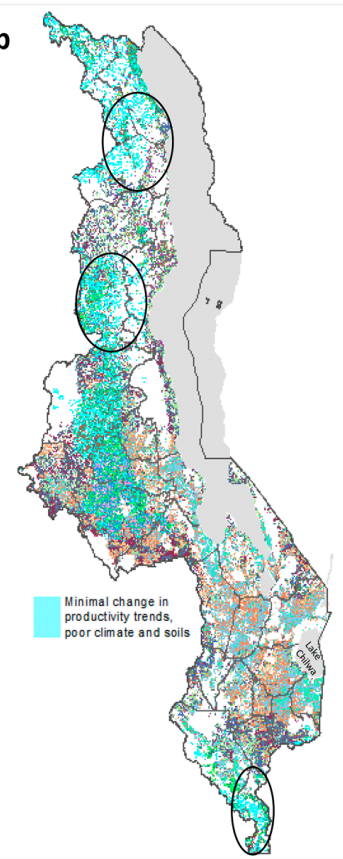

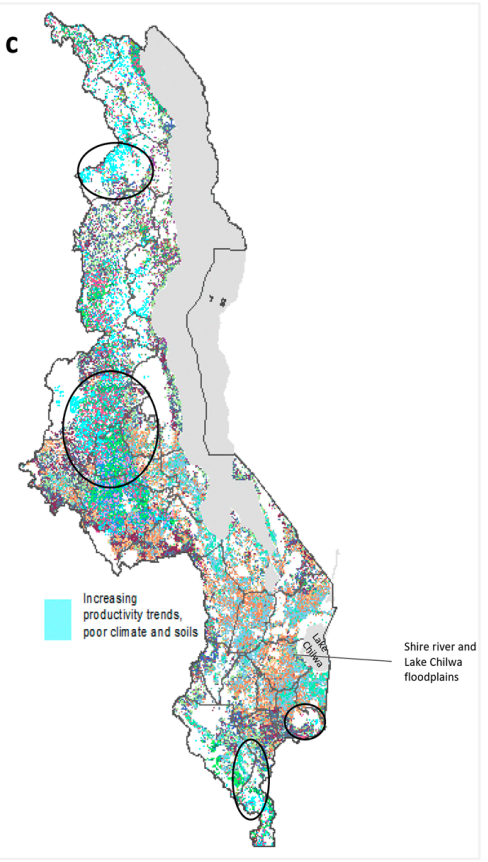

Figure 7. NDVI trend pixels in cyan color, some illustrated in circles, three most likely scenarios on poor climate and soils from above Figure 6 pixel by pixel combinations. (a) Decreasing productivity trends, poor climate, and poor soils. (b) Minimal change in productivity, poor climate, poor soils. (c) Increasing productivity, poor climate, poor soils, deemed to be intensifying areas.
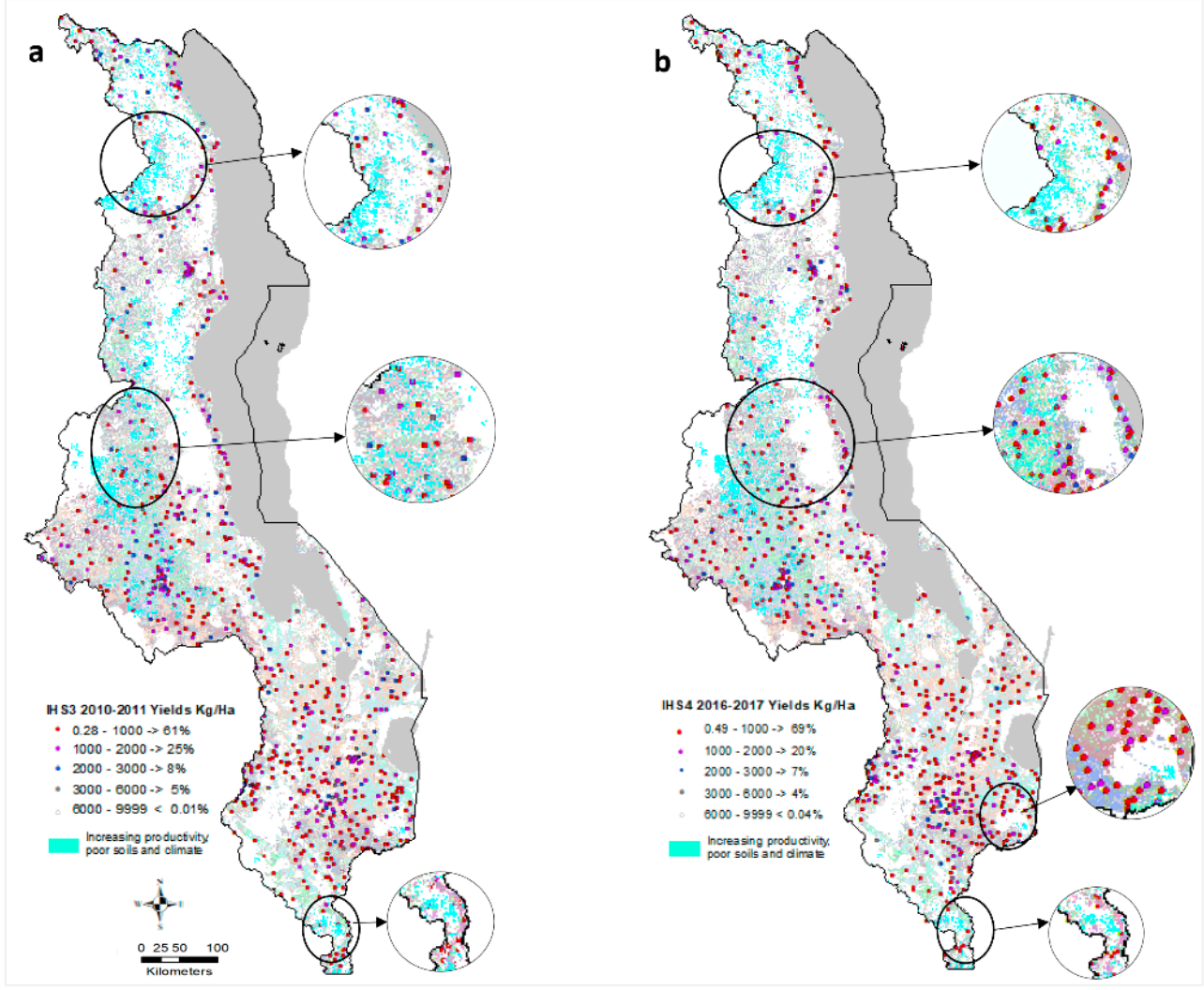

Figure 8. Geographic distribution of (a) households that reported yields for 2010-2011 growing season (source data: LSMS-IHS3 ( $\mathrm{n}=9,939$ households); (b) households that reported yields for 2016-2017 growing season (source data: LSMS-IHS4 ( $\mathrm{n}=10,757$ households) overlaid in the areas predicted to intensify with increasing productivity and poor climate and soils. 
In the 2016-2017 survey, 69\% of farmers reported yields below $1000 \mathrm{Kg} / \mathrm{Ha}$. Of these households, $37 \%$ were located in the south, while $22 \%$ are in central, and the remaining $10 \%$ are found in the north. $20 \%$ reported yields were between 1000 to $2000 \mathrm{Kg} / \mathrm{Ha}$, evenly distributed throughout the central and south regions, with less than $0.5 \%$ in the northern region. $10 \%$ farmers reported yields greater than $3000 \mathrm{Kg} / \mathrm{Ha}$, and these were also mostly located in the southern and central regions (Figure 9a,b).
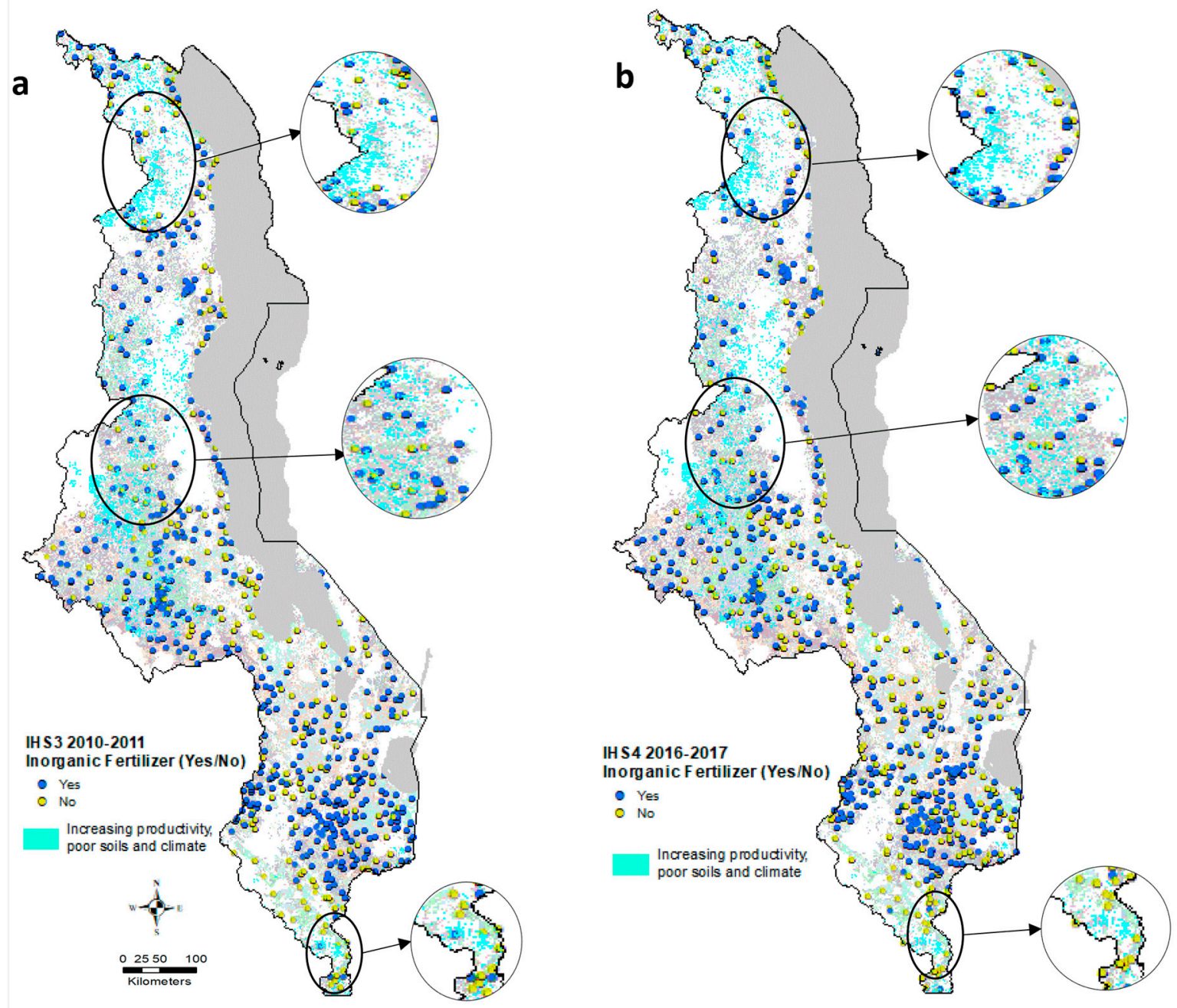

Figure 9. Spatial distribution of households that reported Yes or No to applying (a) inorganic fertilizer to their fields for 2010-2011surveys (source data: LSMS-IHS3 ( $n=9939)$. (b) Households that reported applying inorganic fertilizer to their fields for 2016-2017 surveys (source data: LSMS-IHS3 ( $\mathrm{n}=10,757)$, overlaid in the areas predicted to intensify with increasing productivity and poor climate and soils.

In 2010-2011 surveys, 77\% farmers reported having applied inorganic fertilizer in their plots. Not surprisingly, the majority were located in the southern region of Malawi with the poorest soils (Figure 9a). Likewise, in 2016-2017 surveys, 68\% farmers reported applying inorganic fertilizer, again most commonly in the southern region (Figure $9 \mathrm{~b}$ ).

Figure 10a,b shows the spatial distribution of farmers who reported using organic fertilizer in their plots across Malawi. A proportion of farmers 24\% in 2010-11 survey, and 20\% of farmers in 2016-17 survey reported applying organic fertilizer, and overall livestock presence as a source of organic fertilizer is low, especially in the southern region (Figure 10). 

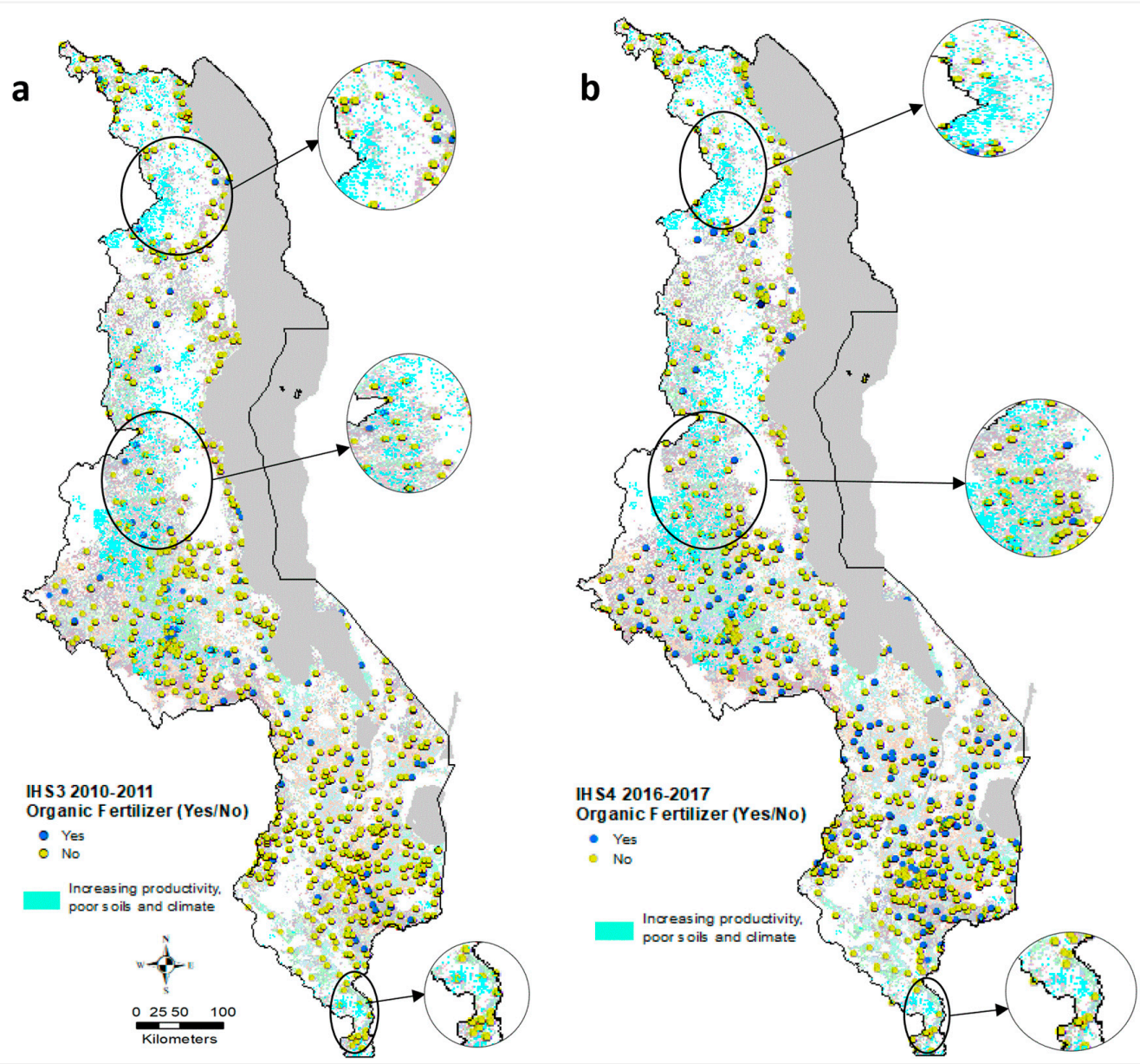

Figure 10. Spatial distribution of (a) households that reported applying organic fertilizer to their fields for 2010-2011 growing season (source data: LSMS-IHS3 ( $=$ 9939); (b) households that reported applying organic fertilizer to their fields for 2016-2017 (source data: LSMS-IHS3 ( $n=10,757)$. Overlaid in the areas predicted to intensify with increasing productivity and poor climate and soils.

Farmers reported their perceptions of their plot soil quality using three categories: Good, fair, and poor ratings. In $2010-11$ surveys, $44 \%$ of farmers perceived plot soil quality to be good, $44 \%$ perceived their soil quality to be fair, while 12\% replied poor for plots' soil quality (Figure 11a). In 2016-2017 surveys, $50 \%$ of farmers rated their plots' soil quality to be good, while $36 \%$ perceived their plot soil quality to be fair, and $14 \%$ perceived their plot quality to be bad (Figure 11b). In both surveys, only $16 \%$ of farmers in the northern region rated their plots' soil quality as bad, and $21 \%$ of farmers found their plots to be fair, while $20 \%$ of farmers reported their plots' soil quality as good. In contrast from the north, over $50 \%$ of farmers in the south rated their plots' soil quality between bad or fair (in both surveys), whereas in the central region, 30\% of farmers rated their plots' soil quality as bad or fair, and a small percentage rated the soil quality as good (Figure 11a,b).

Figure 12 visualizes the pixels identified as intensifying (defined by increasing productivity, poor climate and soils) in Figure 7c. Here, we show land cover during the main growing season-wet season - and the dry season where imagery was available for assessment of the land use in these intensifying pixels. The image data suggest land use with mixed cropping, or under-irrigation. The temporal imagery on these intensification pixels show that the land use (agricultural management activity) identified in these pixels may suggest that these management activities are associated with intensification. 

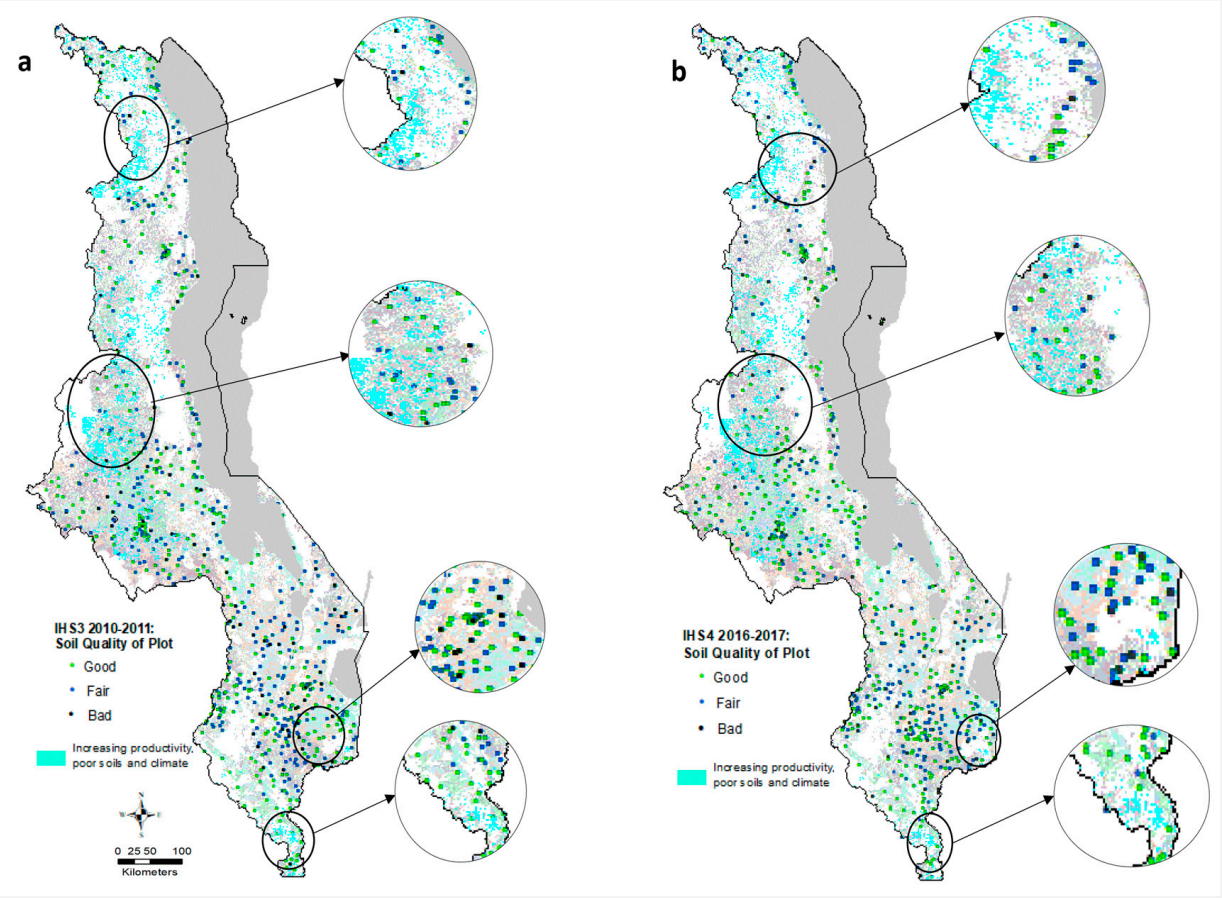

Figure 11. Spatial distribution of farmer response to whether the soil quality was (Good, Fair, or Bad). (a) Farmer responses on soil quality of their plots in 2010-2011 surveys (source data: LSMS-IHS3 ( $n=9939$ ). (b) Soil quality of their plots in 2016-2017 surveys (source data: LSMS-IHS3 $(n=10,757)$. Overlaid to areas predicted to intensify with increasing productivity and poor climate.

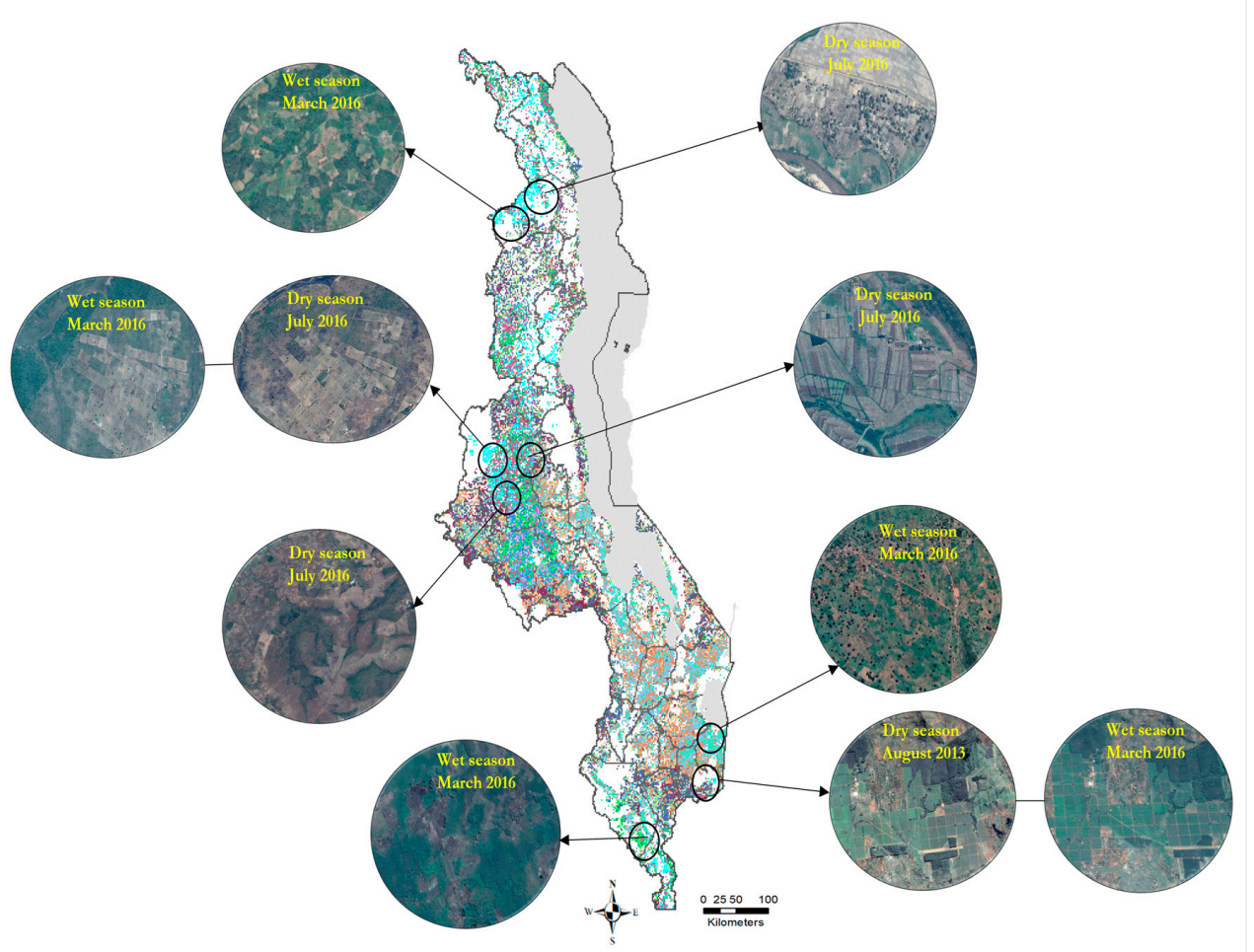

Figure 12. Land use and land cover of available cloud-free satellite imagery of selected intensifying pixels as viewed using Google Earth Pro application. Satellite imagery is Landsat $30 \mathrm{~m}$ resolution. The circles in the map represent the areas in which the imagery was taken (Source: "Malawi", Google earth, 2013, 2016 imagery, August 01 2019). 


\section{Discussion and Conclusions}

\subsection{Malawi's Productivity Trends}

There are few biophysically based longitudinal studies that consider productivity over time, and we know of no other that addresses this in smallholder agriculture in Africa. This critical aspect of agricultural sustainability is evaluated here based on spatial-temporal patterns of intensification of agriculture for maize crop growing season (November to April) from 2006-2017 using generalized models on Malawian farmland productivity trends. We hypothesize that locations with increasing trends in agricultural productivity are intensifying, and specifically highlight areas where productivity trends are increasing and not fully explained by climate trends and soil conditions. Our results partly agree with the [71] study, showing spatial distribution of Malawi's productivity trends as influenced by climatic factors and agricultural input resources.

Increasing productivity in some locations (Figure 7c) with suboptimal climate and soils for maize is evidence of intensifying agriculture across Malawi. We have observed that farmers with farms in these marginal environments are intercropping with legumes, growing a significant number of trees for green manure, or adopting other climate and soil resilient strategies. Previous studies for Malawi that show mixed cropping systems with tree species are widespread, especially in the northern and central regions, nitrogen-fixing trees such as Glirididia sepium, Sesbania sesban, Tephrosia vogeii, and Faidherbia albida, that improve soil fertility, are common [72-75]. Additionally, increasing productivity located close to or within forested areas may suggest forest cover conversion to agriculture. In such areas, few farmers practice shifting cultivation-letting the soil rest in natural forest regenerations or in some cases; slash and burn practices are carried out [73].

Intensifying agriculture located close to lakes and river plains may be further explained by supplemental irrigation. Since early 2000, the government of Malawi has increased supplemental irrigation schemes for small scale farming [76]. Within the lakes and river catchments, ongoing, low-cost, community-led irrigation scheme projects promote sustainable intensification and allow small scale farmers to cultivate diverse crops such as rice, vegetables, or sugarcane through the dry season $[23,77,78]$.

Remote sensing imagery captured intensifying agricultural areas that have mixed cropping and agroforestry practices, and also showed farming landscapes likely involving irrigation. The findings are consistent with studies that note that land access to input resources may boost productivity in changing climates [79-81]. Our findings also show-decreasing productivity trends, especially in the southern region, correlate with a rainfall gradient that follows a north to south pattern [82]. The decreasing productivity across Malawi suggests that the landscape is homogenous in terms of vegetation types and cropping systems; areas with sparse vegetation have effect vegetation apparent reflectance lost due to the soil or bare areas, while in drier areas, the vegetation reflectance values are not expected to change much over time $[55,83]$. Decreasing trends that occur during main growing season, suggest crop failure due to erratic weather across Malawi, as prior extreme weather events, as reported in earlier years 2009, 2012, and 2015, subsequently affected crops in the main growing season [69]. In 2015-2016, Malawi's main growing season experienced late onset of rains, and a prolonged dry spell, possibly driven by El Nino conditions that impacted crop development [84].

\subsection{Malawian Spatial Distribution}

Low productivity was observed in surveys as well as remote sensing. The general spatial observation of lower yield reported in the south is also reflected in FAO statistics, however, the amount is $50 \%$ less from farmer reported survey data here. In the southern region, farmers reported maize yields are less than $2000 \mathrm{~kg}$ per hectare in both surveys, and we attribute this to the fact that farming in the southern region is challenged by dense local populations, and livestock populations competing for the same small land sizes for sustenance. The central and northern regions have dissimilar opportunities and challenges relative to those found in the south. Land resources are abundant in the northern region 
due to lower population density, and thus flexible to crop diversification. Additionally, the majority of land ownership in Malawi is through customary laws, while the rest is either public or private lands [85]. In the central region, farmers typically cultivate small to medium size landholdings, and thus may be involved in cash cropping (e.g., tobacco, cotton, and horticulture], also farmers own small livestock such as goats, pigs, and chickens for food and manure [86]. In the northern region, there are livestock farmers who own cattle and have bigger landholdings, and most of these farmers are from medium to high income households [87].

From both IHS surveys, the majority of farmers reported soil quality as fair or bad. This is likely an indicator of crop health and yield performance history. Previous studies have shown that continuous cultivation in smallholder farming is a major factor contributing to soil degradation, leaving soils depleted of nutrients [16]. The majority of households in central and southern Malawi reported using inorganic fertilizer, however, few households reported using organic manure for soil amelioration, as this resource is linked to ownership of livestock [88]. It is difficult to quantify organic and inorganic fertilizers use and productivity at the national scale due to other unobserved variables, such as field conditions, input application timing, and inorganic fertilizer use associated with access and affordability [89].

Malawi's agricultural practices dissemination is limited by the limited number of extension educators, with extension to farmer ratio ranging from 1:1600 to 1:3000 per district. In contrast, the nationally recommended ratio is extension to farmer of 1:750-1:850 [90]. Some studies also report that resource-poor farmers have limited capacity to participate in extension activities, particularly women farmers $[90,91]$.

While our study provides insights regarding the spatial distribution of agricultural intensification in Malawi, there are limitations. We base our analysis on diverse time series satellite data products available for Malawi, including gridded climate datasets with spatial resolutions ranging from $1 \mathrm{~km}$ to $5 \mathrm{~km}$. These were chosen due to high temporal resolution; however, the spatial resolution is coarse, and if a high spatial resolution product existed, this would enable improved detection of local drivers of agricultural variability [92]. Additionally, sustainability presents an imprecise endpoint and is, as we define it, a trajectory of production resulting from the complex interplay of diverse phenomenon. We acknowledge that we cannot account for all factors nor disentangle all drivers producing particular classes of results measured in pixels. Another challenge is that the two cross-sectional household surveys were not directly comparable since different households were sampled in 2010-2011 versus 2016-2017 surveys. However, the cross-sectional households are considered nationally representative of households.

This study contributes to the literature on agricultural intensification of small scale farming (e.g., [93-95]) by highlighting patterns of increasing productivity not driven by a changing, mesic climate or land suitability. Market access to inputs and outputs, farmer knowledge, and goals are all expected to influence agricultural intensification.

Few studies have focused on trend analysis in resource-poor regions where intensification of agriculture is occurring despite biophysical impediments to productivity. Overall, there are worrying downward productivity trends on Malawi agricultural lands. At the same time, spatial identification of sites associated with agriculture intensification for maize over a 10-year time series suggests that Malawian farmers are adopting and improving the use of available natural and social resources. Such efforts are likely to improve crop productivity over time despite challenging climate, social, and edaphic factors. This research improves our understanding of agricultural intensification at multiple scales, to better inform decision makers on the use of spatial information for targeted solutions that address sustainable intensification of agriculture.

Author Contributions: Conceptualization, J.P.M., S.S., and L.M.M.; methodology, L.M.M., J.P.M., S.S.; writing-original draft preparation, L.M.M., J.P.M., S.S.; writing-review and editing, S.S., J.P.M., and L.M.M.; funding acquisition, J.P.M. and S.S. All authors have read and agreed to the published version of the manuscript. 
Funding: This study is made possible by the support of the American People provided to the Feed the Future Innovation Lab for Sustainable Intensification through the United States Agency for International Development (USAID). The contents are the sole responsibility of the authors and do not necessarily reflect the views of USAID or the United States Government. Program activities are funded by USAID under Cooperative Agreement No. AID-OAA-L-14-00006.

Acknowledgments: We express our sincere gratitude to the reviewers for their contribution, Shiqi Tao for her technical assistance, and Brad Peter for his spatial visualization expertise. Any remaining errors are entirely our responsibility.

Conflicts of Interest: The authors declare that the research was conducted in the absence of any commercial or financial relationships that could be construed as a potential conflict of interest.

\section{References}

1. Power, A.G. Ecosystem services and agriculture: Tradeoffs and synergies. Philos. Trans. R. Soc. B Biol. Sci. 2010, 365, 2959-2971. [CrossRef]

2. Simelton, E.; Ostwald, M. Multifunctional Land Uses in Africa (Open Access): Sustainable Food Security Solutions. Routledge 2019, 193, 5-10. Available online: https://play.google.com/books/reader? $\mathrm{id}=$ KOyjDwAAQBAJ\&hl=en\&pg=GBS.PA5. (accessed on 8 August 2019).

3. Potter, C.S.; Klooster, S.; Brooks, V. Interannual Variability in Terrestrial Net Primary Production: Exploration of Trends and Controls on Regional to Global Scales. Ecosystems 1999, 2, 36-48. [CrossRef]

4. Foley, J.A.; DeFries, R.; Asner, G.P.; Barford, C.; Bonan, G.; Carpenter, S.R.; Chapin, F.S.; Coe, M.T.; Daily, G.C.; Gibbs, H.K.; et al. Global Consequences of Land Use. Science 2005, 309, 570-574. [CrossRef] [PubMed]

5. Wheeler, T.; Von Braun, J. Climate Change Impacts on Global Food Security. Science 2013, 341, 508-513. [CrossRef] [PubMed]

6. Hazell, P.; Poulton, C.; Wiggins, S.; Dorward, A. The Future of Small Farms: Trajectories and Policy Priorities. World Dev. 2010, 38, 1349-1361. [CrossRef]

7. Chamberlin, J.; Jayne, T.S.; Headey, D. Scarcity amidst abundance? Reassessing the potential for cropland expansion in Africa. Food Policy 2014, 48, 51-65. [CrossRef]

8. Godfray, H.C.; Garnett, T. Food security and sustainable intensification. Philos. Trans. R. Soc. B Biol. Sci. 2014, 369, 20120273. [CrossRef]

9. Pretty, J.N. The sustainable intensification of agriculture. Nat. Resour. Forum. 1997, 21, 247-256. [CrossRef]

10. Pretty, J.; Toulmin, C.; Williams, S. Sustainable intensification in African agriculture. Int. J. Agric. Sustain. 2011, 9, 5-24. [CrossRef]

11. Gunton, R.M.; Firbank, L.G.; Inman, A.; Winter, D.M. How scalable is sustainable intensification? Nat. Plants 2016, 2, 1-4. [CrossRef] [PubMed]

12. Petersen, B.; Snapp, S. What is sustainable intensification? Views from experts. Land Use Policy 2015, 46, 1-10. [CrossRef]

13. Loos, J.; Abson, D.J.; Chappell, M.J.; Hanspach, J.; Mikulcak, F.; Tichit, M.; Fischer, J. Putting meaning back into "sustainable intensification". Front. Ecol. Environ. 2014, 12, 356-361. [CrossRef]

14. Kumbuyo, C.P.; Yasuda, H.; Kitamura, Y.; Shimizu, K. Fluctuation of rainfall time series in Malawi: An analysis of selected areas. Geofizika 2014, 31, 13-28. [CrossRef]

15. Haghtalab, N.; Moore, N.; Ngongondo, C. Spatio-temporal analysis of rainfall variability and seasonality in Malawi. Reg. Environ. Change 2019. [CrossRef]

16. Snapp, S.S.; Mafongoya, P.L.; Waddington, S. Organic matter technologies for integrated nutrient management in smallholder cropping systems of southern Africa. Agric. Ecosyst. Environ. 1998, 71, 185-200. [CrossRef]

17. Mulwafu, W.O. Conservation Song: A History of Peasant-State Relations and The Environment in Malawi, 1860-2000; White Horse Press: Cambridge, UK, 2011; p. 269.

18. Misselhorn, A.A. What drives food insecurity in southern Africa? A meta-analysis of household economy studies. Glob. Environ. Change 2005, 15, 33-43. [CrossRef]

19. Chirwa, E.; Dorward, A. Agricultural Input Subsidies: The Recent Malawi Experience; OUP: Oxford, UK, 2013; p. 315.

20. Masangano, C.M.; Chiwasa, H.; Kambewa, D.K.; Kakwera, M.; Chimombo, M.; Matita, M.; Gausi, W. Making the demand driven extensions services systems work through decentralised structures: Prospects for the future extension service delivery in Malawi. J. Agric. Ext. Rural Dev. 2016, 8, 240-249. 
21. Messina, J.P.; Peter, B.G.; Snapp, S.S. Re-evaluating the Malawian Farm Input Subsidy Programme. Nat. Plants 2017, 3, 17013. [CrossRef]

22. Peter, B.G.; Messina, J.P.; Snapp, S.S. A Multiscalar Approach to Mapping Marginal Agricultural Land: Smallholder Agriculture in Malawi. Ann. Am. Assoc. Geogr. 2018, 108, 989-1005. [CrossRef]

23. Nhamo, L.; Mabhaudhi, T.; Magombeyi, M. Improving Water Sustainability and Food Security through Increased Crop Water Productivity in Malawi. Water 2016, 8, 411. [CrossRef]

24. MoAIWD. Ministry of Agriculture, Irrigation \& Water Development, Republic of Malawi. 2019. Available online: https://www.agriculture.gov.mw/ (accessed on 29 June 2019).

25. Malawi Government. National Agriculture Policy. 2016. Available online: https://reliefweb.int/sites/ reliefweb.int/files/resources/NAP_Final_Signed.pdf (accessed on 29 June 2019).

26. Jones, A.D.; Shrinivas, A.; Bezner-Kerr, R. Farm production diversity is associated with greater household dietary diversity in Malawi: Findings from nationally representative data. Food Policy 2014, 46, 1-12. [CrossRef]

27. Kane, D.A.; Rogé, P.; Snapp, S.S. A Systematic Review of Perennial Staple Crops Literature Using Topic Modeling and Bibliometric Analysis. PLoS ONE 2016, 11, e0155788. [CrossRef] [PubMed]

28. Rogé, P.; Snapp, S.; Kakwera, M.N.; Mungai, L.; Jambo, I.; Peter, B. Ratooning and perennial staple crops in Malawi. A review. Agron. Sustain. Dev. 2016, 36, 50. [CrossRef]

29. Nijbroek, R.P.; Andelman, S.J. Regional suitability for agricultural intensification: A spatial analysis of the Southern Agricultural Growth Corridor of Tanzania. Int. J. Agric. Sustain. 2016, 14, 231-247. [CrossRef]

30. You, L.; Wood, S.; Wood-Sichra, U. Generating plausible crop distribution maps for Sub-Saharan Africa using a spatially disaggregated data fusion and optimization approach. Agric. Syst. 2009, 99, 126-140. [CrossRef]

31. Atzberger, C. Advances in Remote Sensing of Agriculture: Context Description, Existing Operational Monitoring Systems and Major Information Needs. Remote Sens. 2013, 5, 949-981. [CrossRef]

32. Bockstaller, C.; Girardin, P.; van der Werf, H.M.G. Use of Agro-Ecological Indicators for the Evaluation of Farming Systems. Available online: http://www.sciencedirect.com/science/article/pii/S0378519X97800323 (accessed on 3 March 2018).

33. Rigby, D.; Woodhouse, P.; Young, T.; Burton, M. Constructing a farm level indicator of sustainable agricultural practice. Ecol. Econ. 2001, 39, 463-478. [CrossRef]

34. Anyamba, A.; Tucker, C.J. Analysis of Sahelian vegetation dynamics using NOAA-AVHRR NDVI data from 1981-2003. J. Arid. Environ. 2005, 63, 596-614. [CrossRef]

35. Dembélé, M.; Zwart, S.J. Evaluation and comparison of satellite-based rainfall products in Burkina Faso, West Africa. Int. J. Remote Sens. 2016, 37, 3995-4014.

36. Pan, W.K.Y.; Walsh, S.J.; Bilsborrow, R.E.; Frizzelle, B.G.; Erlien, C.M.; Baquero, F. Farm-level models of spatial patterns of land use and land cover dynamics in the Ecuadorian Amazon. Agric. Ecosyst. Environ. 2004, 101, 117-134. [CrossRef]

37. Rojas, O.; Vrieling, A.; Rembold, F. Assessing drought probability for agricultural areas in Africa with coarse resolution remote sensing imagery. Remote Sens. Environ. 2011, 115, 343-352. [CrossRef]

38. Vancutsem, C.; Ceccato, P.; Dinku, T.; Connor, S.J. Evaluation of MODIS land surface temperature data to estimate air temperature in different ecosystems over Africa. Remote Sens. Environ. 2010, 114, 449-465. [CrossRef]

39. Ngongondo, C.; Xu, C.-Y.; Gottschalk, L.; Alemaw, B. Evaluation of spatial and temporal characteristics of rainfall in Malawi: A case of data scarce region. Theor. Appl. Climatol. 2011, 106, 79-93. [CrossRef]

40. Dijkshoorn, J.A.; Leenaars, J.G.B.; Huting, J.; Kempen, B. Soil and Terrain database of the Republic of Malawi. Available online: https://www.isric.org/documents/document-type/isric-report-201601-soil-andterrain-database-republic-malawi/ (accessed on 19 March 2019).

41. Todd, B.; Athur, M.; Flora, N. Detailed crop suitability maps and an agricultural zonation scheme for Malawi: Spatial information for agricultural planning purposes. Available online: https://www.ifpri.org/ publication/detailed-crop-suitability-maps-and-agricultural-zonation-scheme-malawi-spatial (accessed on 19 January 2019).

42. Kalanda-Joshua, M.; Ngongondo, C.; Chipeta, L.; Mpembeka, F. Integrating indigenous knowledge with conventional science: Enhancing localised climate and weather forecasts in Nessa, Mulanje, Malawi. Phys. Chem. Earth Parts ABC 2011, 36, 996-1003. [CrossRef] 
43. Why Population Matters to Malawi's Development-Population Reference Bureau. Available online: https://www.prb.org/malawi-population-2012/ (accessed on 21 May 2019).

44. Davis, B.; Winters, P.; Carletto, G.; Covarrubias, K.; Quiñones, E.J.; Zezza, A.; Stamoulis, K.; Azzarri, C.; DiGiuseppe, S. A Cross-Country Comparison of Rural Income Generating Activities. World Dev. 2010, 38, 48-63. [CrossRef]

45. UN DESA. United Nations, Department of Economic and Social Affairs/Population Division. 2018. Available online: https://population.un.org/wup/Country-Profiles/ (accessed on 9 February 2019).

46. Didan, K. MOD13Q1 MODIS/Terra Vegetation Indices 16-Day L3 Global 250 m SIN Grid V006. 2015, distributed by NASA EOSDIS Land Processes DAAC. 2015. Available online: https://doi.org/10.5067/MODIS/ MOD13Q1.006 (accessed on 29 November 2019).

47. Funk, C.; Peterson, P.; Landsfeld, M.; Pedreros, D.; Verdin, J.; Shukla, S.; Husak, G.; Rowland, J.; Harrison, L.; Hoell, A.; et al. The climate hazards infrared precipitation with stations-A new environmental record for monitoring extremes. Sci. Data 2015, 2,1-21. [CrossRef]

48. Hook, W.Z.; Hulley, G. MOD11A2 MODIS/Terra Land Surface Temperature/Emissivity 8-Day L3 Global 1km SIN Grid V006 [Data set]. 2015. Available online: https://doi.org/10.5067/MODIS/MOD11A2.006 (accessed on 29 November 2019).

49. Friedl, M.; Sulla-Menashe, D. MCD12Q1 MODIS/Terra+Aqua Land Cover Type Yearly L3 Global 500 m SIN Grid V006 [Data set]. NASA EOSDIS Land Processes DAAC. 2019. Available online: https: //doi.org/10.5067/MODIS/MCD12Q1.006 (accessed on 29 November 2019).

50. ESA 2010 and UCLouvain. GlobCover. Available online: http://due.esrin.esa.int/page_globcover.php (accessed on 23 November 2018).

51. $300 \mathrm{~m}$ Annual Global Land Cover Time Series from 1992 to 2015. Website. Available online: https: //www.esa-landcover-cci.org/?q=node/175 (accessed on 23 November 2018).

52. Li, G.; Messina, J.P.; Peter, B.G.; Snapp, S.S. Mapping Land Suitability for Agriculture in Malawi. Land Degrad. Dev. 2017, 28, 2001-2016. [CrossRef]

53. Reed, B.C.; Brown, J.F.; VanderZee, D.; Loveland, T.R.; Merchant, J.W.; Ohlen, D.O. Measuring phenological variability from satellite imagery. J. Veg. Sci. 1994, 5, 703-714. [CrossRef]

54. De Jong, R.; de Bruin, S. Linear trends in seasonal vegetation time series and the modifiable temporal unit problem. Biogeosciences 2012, 9, 71-77. [CrossRef]

55. Fensholt, R.; Rasmussen, K.; Nielsen, T.T.; Mbow, C. Evaluation of earth observation based long term vegetation trends-Intercomparing NDVI time series trend analysis consistency of Sahel from AVHRR GIMMS, Terra MODIS and SPOT VGT data. Remote Sens. Environ. 2009, 113, 1886-1898. [CrossRef]

56. Gorelick, N.; Hancher, M.; Dixon, M.; Ilyushchenko, S.; Thau, D.; Moore, R. Google Earth Engine: Planetary-scale geospatial analysis for everyone. Remote Sens. Environ. 2017, 202, 18-27. [CrossRef]

57. De Jong, R.; de Bruin, S.; de Wit, A.; Schaepman, M.E.; Dent, D.L. Analysis of monotonic greening and browning trends from global NDVI time-series. Remote Sens. Environ. 2011, 115, 692-702. [CrossRef]

58. Kendall, M.G. Rank Correlation Methods; Griffin: Oxford, UK, 1948.

59. Theil, H. A Rank-Invariant Method of Linear and Polynomial Regression Analysis. Available online: https://doi.org/10.1007/978-94-011-2546-8_20 (accessed on 16 August 2019).

60. Forkel, M.; Carvalhais, N.; Verbesselt, J.; Mahecha, M.D.; Neigh, C.S.R.; Reichstein, M. Trend Change Detection in NDVI Time Series: Effects of Inter-Annual Variability and Methodology. Remote Sens. 2013, 5, 2113-2144. [CrossRef]

61. Verbesselt, J.; Hyndman, R.; Newnham, G.; Culvenor, D. Detecting trend and seasonal changes in satellite image time series. Remote Sens. Environ. 2010, 114, 106-115. [CrossRef]

62. Food and Agriculture Organization of the United Nations. Available online: http://www.fao.org/news/ archive/news-by-date/2019/en/ (accessed on 16 August 2019).

63. National Statistical Office (NSO). Malawi Living Standards Measurement Survey, Third Integrated Household Survey 2010-2011. Available online: https://microdata.worldbank.org/index.php/catalog/1003/get-microdata (accessed on 2 February 2018).

64. National Statistical Office (NSO). Malawi Living Standards Measurement Survey, Fourth Integrated Household Survey 2016-2017. Available online: https:/microdata.worldbank.org/index.php/catalog/2936/ get-microdata (accessed on 2 February 2018). 
65. National Statistical Office of Malawi. Available online: http://www.nsomalawi.mw/ (accessed on 2 February 2018).

66. World Bank 2020. Available online: https:/www.worldbank.org/en/country/malawi/overview (accessed on 29 January 2020).

67. Malawi PDNA 2015 Draft Report. Available online: https://www.gfdrr.org/sites/default/files/150528_ MALAWI\%20PDNA\%202015\%20DRAFT\%20REPORT\%20V1.pdf (accessed on 27 November 2019).

68. Snapp, S.S. Soil nutrient status of smallholder farms in Malawi. Commun. Soil. Sci. Plant Anal. 1998, 29, 2571-2588. [CrossRef]

69. Malawi Drought 2016 PDNA. Available online: https://www.recoveryplatform.org/assets/publication/PDNA/ CountryPDNAs/Malawi_Drought_2016_PDNA.PDF (accessed on 18 March 2019).

70. Malawi 2019 Floods Post Disaster Needs Assessment Report. Available online: https://reliefweb.int/report/ malawi/malawi-2019-floods-post-disaster-needs-assessment-report (accessed on 29 November 2019).

71. Galford, G.L.; Fiske, G.J.; Sedano, F.; Michelson, H. Remote Sensing Analysis of Malawi's Agricultural Inputs Subsidy and Climate Variability Impacts on Productivity. Available online: http://adsabs.harvard.edu/abs/ 2016AGUFMGC53A1271G (accessed on 15 August 2019).

72. Coulibaly, J.Y.; Chiputwa, B.; Nakelse, T.; Kundhlande, G. Adoption of agroforestry and the impact on household food security among farmers in Malawi. Agric. Syst. 2017, 155, 52-69. [CrossRef]

73. Kaczan, D.; Arslan, A.; Lipper, L. Climate-Smart Agriculture? A Review of Current Practice of Agroforestry and Conservation Agriculture in Malawi and Zambia. AgEcon Search. 2013. Available online: https: //ageconsearch.umn.edu/record/288985 (accessed on 18 July 2019).

74. Kwesiga, F.; Akinnifesi, F.K.; Mafongoya, P.L.; McDermott, M.H.; Agumya, A. Agroforestry research and development in southern Africa during the 1990s: Review and challenges ahead. Agrofor. Syst. 2003, 59, 173-186. [CrossRef]

75. Thangata, P.H.; Alavalapati, J.R.R. Agroforestry adoption in southern Malawi: The case of mixed intercropping of Gliricidia sepium and maize. Agric. Syst. 2003, 78, 57-71. [CrossRef]

76. Kumwenda, I.; van Koppen, B.; Matete, M.; Nhamo, L. Trends and Outlook: Agricultural Water Management in Southern Africa. Available online: https://www.agrilinks.org/sites/default/files/resource/files/IWMI\% 20Synthesis\%20report\%20agwater\%20management\%20in\%20SADC.pdf (accessed on 13 August 2019).

77. Mwase, W.; Mtethiwa, A.T.; Makonombera, M. Climate Change adaptation practices for two communities in Southern Malawi. Available online: https://www.iiste.org/Journals/index.php/JEES/article/view/10592 (accessed on 15 August 2019).

78. Food and Agriculture Organization of the United Nations. Available online: http://www.fao.org/agwa/ resources/publications/en/ (accessed on 27 November 2019).

79. Campbell, B.M.; Thornton, P.; Zougmoré, R.; van Asten, P.; Lipper, L. Sustainable intensification: What is its role in climate smart agriculture? Curr. Opin. Environ. Sustain. 2014, 8, 39-43. [CrossRef]

80. Hammond, J.; Fraval, S.; Van Etten, J.; Suchini, J.G.; Mercado, L.; Pagella, T.; Frelat, R.; Lannerstad, M.; Douxchamps, S.; Teufel, N.; et al. The Rural Household Multi-Indicator Survey (RHoMIS) for rapid characterisation of households to inform climate smart agriculture interventions: Description and applications in East Africa and Central America. Agric. Syst. 2017, 151, 225-233. [CrossRef]

81. Mbow, C.; Van Noordwijk, M.; Luedeling, E.; Neufeldt, H.; Minang, P.A.; Kowero, G. Agroforestry solutions to address food security and climate change challenges in Africa. Curr. Opin. Environ. Sustain. 2014, 6, 61-67. [CrossRef]

82. Davenport, M.L.; Nicholson, S.E. On the relation between rainfall and the Normalized Difference Vegetation Index for diverse vegetation types in East Africa. Int. J. Remote Sens. 1993, 14, 2369-2389. [CrossRef]

83. Chavula, G.; Brezonik, P.; Bauer, M. Land use and land cover change (LULC) in the Lake Malawi Drainage Basin, 1982-2005. Int. J. Geosci. 2011, 2, 172-178. [CrossRef]

84. World Bank. Malawi Drought 2015-2016: Post-Disaster Needs Assessment (PDNA). 2016. Available online: http://documents.worldbank.org/curated/en/640011479881661626/Malawi-drought-2015-2016-postdisaster-needs-assessment-PDNA (accessed on 29 November 2019).

85. Kishindo, P. Customary land tenure and the new land policy in Malawi. J. Contemp. Afr. Stud. 2004, 22, 213-225. [CrossRef]

86. Productivity and Survival Ability of Goats in Smallholder Crop/Livestock Farming Systems in Malawi. Available online: http://www.lrrd.cipav.org.co/lrrd18/1/chik18007.htm (accessed on 19 October 2019). 
87. Malawi Country Profile. Available online: https://mw.one.un.org/country-profile/ (accessed on 27 November 2019).

88. Tittonell, P.; Gérard, B.; Erenstein, O. Tradeoffs around crop residue biomass in smallholder crop-livestock systems-What's next? Agric. Syst. 2015, 134, 119-128. [CrossRef]

89. Ragasa, C.; Mazunda, J. The impact of agricultural extension services in the context of a heavily subsidized input system: The case of Malawi. World Dev. 2018, 105, 25-47. [CrossRef]

90. Masangano, C.; Mthinda, C. Pluralistic Extension System in Malawi. Available online: https:// www.researchgate.net/publication/254416842_Pluralistic_Extension_System_in_Malawi (accessed on 31 January 2020).

91. Kundhlande, G.; Franzel, S.; Simpson, B.; Gausi, E. Farmer-to-Farmer Extension Approach in Malawi: A Survey of Organizations. Available online: https://www.researchgate.net/publication/275154988_Farmerto-farmer_extension_approaches_in_Malawi_a_survey_of_organizations (accessed on 1 August 2019).

92. Xu, Y.; Yu, L.; Zhao, F.R.; Cai, X.; Zhao, J.; Lu, H.; Gong, P. Tracking annual cropland changes from 1984 to 2016 using time-series Landsat images with a change-detection and post-classification approach: Experiments from three sites in Africa. Remote Sens. Environ. 2018, 218, 13-31. [CrossRef]

93. Franke, A.C.; van den Brand, G.J.; Giller, K.E. Which farmers benefit most from sustainable intensification? An ex-ante impact assessment of expanding grain legume production in Malawi. Eur. J. Agron. 2014, 58, 28-38. [CrossRef]

94. Garnett, T.; Appleby, M.C.; Balmford, A.; Bateman, I.J.; Benton, T.G.; Bloomer, P.; Burlingame, B.; Dawkins, M.; Dolan, L.; Fraser, D.; et al. Sustainable Intensification in Agriculture: Premises and Policies. Science 2013, 341, 33-34. [CrossRef]

95. Snapp, S.; Pound, B. Chapter 4-Farming Systems for Sustainable Intensification. Available online: http://www.sciencedirect.com/science/article/pii/B9780128020708000049 (accessed on 16 August 2019).

(C) 2020 by the authors. Licensee MDPI, Basel, Switzerland. This article is an open access article distributed under the terms and conditions of the Creative Commons Attribution (CC BY) license (http://creativecommons.org/licenses/by/4.0/). 